\title{
SOEP
}

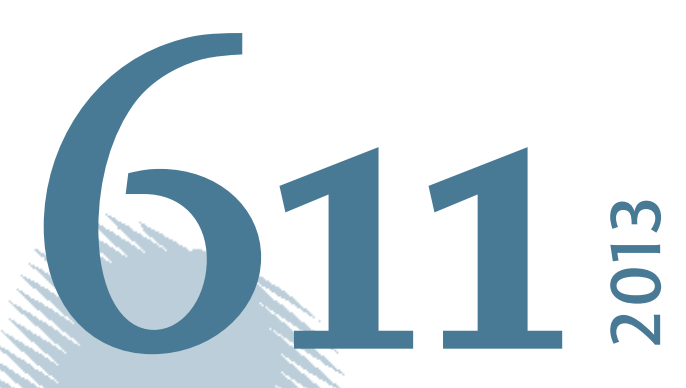

SOEPpapers

on Multidisciplinary Panel Data Research

\section{To own or not to own? Household portfolios, demographics and institutions in a cross-national perspective}

Eva Sierminska and Karina Doorley 


\section{SOEPpapers on Multidisciplinary Panel Data Research}

at DIW Berlin

This series presents research findings based either directly on data from the German SocioEconomic Panel Study (SOEP) or using SOEP data as part of an internationally comparable data set (e.g. CNEF, ECHP, LIS, LWS, CHER/PACO). SOEP is a truly multidisciplinary household panel study covering a wide range of social and behavioral sciences: economics, sociology, psychology, survey methodology, econometrics and applied statistics, educational science, political science, public health, behavioral genetics, demography, geography, and sport science.

The decision to publish a submission in SOEPpapers is made by a board of editors chosen by the DIW Berlin to represent the wide range of disciplines covered by SOEP. There is no external referee process and papers are either accepted or rejected without revision. Papers appear in this series as works in progress and may also appear elsewhere. They often represent preliminary studies and are circulated to encourage discussion. Citation of such a paper should account for its provisional character. A revised version may be requested from the author directly.

Any opinions expressed in this series are those of the author(s) and not those of DIW Berlin. Research disseminated by DIW Berlin may include views on public policy issues, but the institute itself takes no institutional policy positions.

The SOEPpapers are available at

http://www.diw.de/soeppapers

\section{Editors:}

Jürgen Schupp (Sociology)

Gert G. Wagner (Social Sciences, Vice Dean DIW Graduate Center)

Conchita D'Ambrosio (Public Economics)

Denis Gerstorf (Psychology, DIW Research Director)

Elke Holst (Gender Studies, DIW Research Director)

Frauke Kreuter (Survey Methodology, DIW Research Professor)

Martin Kroh (Political Science and Survey Methodology)

Frieder R. Lang (Psychology, DIW Research Professor)

Henning Lohmann (Sociology, DIW Research Professor)

Jörg-Peter Schräpler (Survey Methodology, DIW Research Professor)

Thomas Siedler (Empirical Economics)

C. Katharina Spieß (Empirical Economics and Educational Science)

ISSN: 1864-6689 (online)

German Socio-Economic Panel Study (SOEP)

DIW Berlin

Mohrenstrasse 58

10117 Berlin, Germany

Contact: Uta Rahmann | soeppapers@diw.de 


\title{
To own or not to own? Household portfolios, demographics and institutions in a cross-national perspective. ${ }^{*}$
}

\author{
Eva Sierminska ${ }^{\dagger}$ \\ CEPS/INSTEAD, Luxembourg, DIW Berlin and IZA Bonn \\ Karina Doorley ${ }^{\ddagger}$ \\ IZA Bonn and CEPS/INSTEAD, Luxembourg
}

November 2013

\begin{abstract}
Using harmonized wealth data and a novel decomposition approach, we show that cohort effects exist in the income profiles of asset and debt portfolios for a sample of European countries, the U.S. and Canada. We find that younger households' participation decisions in assets are more responsive to income than older households. Family structure plays a significant role in explaining cross-country differences for both cohorts. Examining institutional differences, we find that in more financially developed and economically open countries, households are less likely to own housing but more likely to be in debt. Typical mortgage characteristics and mathematical literacy are also correlated with debt participation across countries. These findings have important implications for policy setting during times of financial unease for the young, as well as for the future in helping secure adequate income for the elderly. Our results show that there is scope for policies which promote asset participation for young households and debt participation, where there is a need for consumption smoothing, for older households.
\end{abstract}

${ }^{*}$ We would like to thank seminar participants at IZA, CEPS/INSTEAD, Bank of France, INED, University of Graz and ECINEQ conference participants for helpful suggestions and comments. This research is part of the WealthPort project (Household Wealth Portfolios in a Comparative Perspective) supported by the Luxembourg 'Fonds National de la Recherche' (contract CORE C09/LM/04) and by core funding for CEPS/INSTEAD by the Ministry of Higher Education and Research of Luxembourg. An earlier version of this paper is entitled: Decomposing household wealth portfolios across countries: An age-old question?

${ }^{\dagger}$ Eva Sierminska, CEPS/INSTEAD, 3, avenue de la Fonte, L-4364 Esch-sur-Alzette, Luxembourg. Phone: +352 585855409. Fax: +352 585560. E-mail: eva. sierminska@ceps. Iu.

${ }_{\ddagger}^{\ddagger}$ Karina Doorley, IZA, Schaumburg-Lippe Str. 5-9, 53113 Bonn, Germany. Phone: +49 (228) 3894-420. E-mail: doorleyeiza.org. 


\section{Introduction}

There has been growing interest in studying household wealth portfolios for several reasons. On the one hand, population aging has raised questions about the long-term sustainability of pension systems and the need to assess the adequacy of saving for retirement through the study of the level and composition of assets with which households retire (e.g. Chiuri and Jappelli (2010), Gornick et al. (2009)). On the other hand, the lasting effects of the crisis and the resulting meltdown and subsequent appreciation of assets has had different repercussions across various demographic groups. In addition, the growing complexities of wealth portfolios and the growing efforts to create a more unified market for consumers has sparked a literature on comparing the diversity of wealth portfolios. Finally, there is a growing interest in behavioral finance which acknowledges the existence of demographic differences in household investment behavior (in contrast to some theoretical models) and in addressing these difference with appropriate policy instruments that could have the desired effect on wealth or debt accumulation (Campbell (2006)).

Researchers have found that, despite greater integration of asset and labor market policies in Europe, differences in market conditions among European countries are much more pronounced than within the US and that large differences in investment patterns still exist in European countries, even after controlling for other household characteristics. This has been found to be the case for mature households (Christelis et al. (2012)), for debt (Crook and Hochguertel (2007)) and for stockholding (Guiso et al. (2003)).

Nevertheless, despite several attempts, the literature on international portfolios is not abundant. Single or two-country studies are more common than cross-country comparisons due to data availability and difficulties in performing cross-national comparisons. The few sources of cross-country wealth data that do exist are, generally, not directly comparable due to differences in data collection techniques, which are shaped by the institutional environment and, indirectly, by the available wealth instruments. Consequently, a better understanding of what is captured by wealth survey data requires some knowledge of institutions. For example, a high take-up of individual loans in the US is driven by less severe credit restraints than in other countries.

Comparable cross-country data is not easily available. For example, the Survey of Health, Aging and Retirement in Europe (SHARE) captures individuals 50 and over. The Household Finance and Consumption Survey (HFCS) is available for euro-zone countries only 
and some very recent studies (e.g., Bover et al. (2013)) use this to analyze wealth portfolios across countries during the crisis period. Another option for researchers is to rely on data in the Luxembourg Wealth Study, which has thoroughly examined and harmonized comparable and non-comparable components of wealth and has made a detailed study of country wealth components and institutions. This approach facilitates an insightful analysis of wealth portfolios across countries and allows comparisons across European, as well as non-European countries.

In this paper we follow this approach and use the conceptual framework developed by the Luxembourg Wealth Study, but apply it to independent data. We use two datasets that are used in the Household Finance and Consumption Survey (Italy and Spain) (but for the pre-HFCS years) and are publicly available. In addition, we use data for Canada, Germany, Luxembourg and the United States, thus providing a unique pre-crisis view of household wealth portfolios in a cross-national perspective.

Our paper is novel in several ways. Apart from using data for a unique set of countries with differential institutional backgrounds, we identify differences in asset portfolios across countries, focusing on differences between older and younger cohorts. ${ }^{1}$ Third, we extend the approach of Christelis et al. (2012) by disaggregating the effect of covariates in the participation decision to discover which household characteristics contribute the most to differences in wealth holdings across countries. ${ }^{2}$ Our focus remains on the main assets and liabilities held by households; financial assets, main residence, investment real estate; mortgages and non-housing debt. ${ }^{3}$

Past research suggests a large role for institutions in explaining cross-national differences in portfolios for the older population. We show that the role of characteristics is more important than previously thought. Based on surveys for the whole population, we confirm that characteristics play a relatively minor role in the decision to participate in financial assets or principal residence investment for the over-50 population, but they do play a role for the younger cohort, particularly when it comes to asset participation. Financial assets are, for example, very sensitive to income for the young. Differences in family structure at certain ages also explains a non-negligible share of cross-country differences. Younger households' participation decisions in assets also respond more to the institutional setting

\footnotetext{
${ }^{1}$ In our reported analysis in this paper, we ultimately focus on the younger cohort and a comparison with more mature households, as our previous work pointed to significant differences among the two.

${ }^{2}$ Sierminska et al. (2010) for example, show that labor market differences between men and women explain the majority of wealth differences and work in the opposite direction to demographic factors.

${ }^{3}$ Although we do not take into account other factors such as different risks and returns for financial assets it has been shown that the majority of households have only a few types of assets. Less than $35 \%$ of households in the U.S. hold risky assets in the form of stocks or mutual funds and this number is much lower for the other countries.
} 
than mature households while mature households debt decisions respond more to the institutional setting than younger households. This result has implications for policy setting during times of financial unease and for retirement planning. Measures to consider are the promotion of savings and investment behavior for the young, in anticipation of their retirement and the encouragement of debt holding, e.g., reverse mortgages, for the older cohort in order to smooth their consumption during retirement.

In Section 2 we describe the data. Section 3 overviews the decomposition method for participation and discusses basic characteristics of wealth portfolios in our sample of countries. The results are in Section 4 and Section 5 concludes.

\section{Data}

In our sample, we use data for two North American countries: Canada and the US, and several European countries with varying institutional and welfare regimes: Germany, Italy, Luxembourg and Spain. At the time of data collection, all of these countries were in a pre-crisis stage with low unemployment and positive GDP growth (Table 1) ${ }^{4}$. The data for Canada come from the 2005 Survey of Financial Security, for Germany the 2007 wealth module of the Socio-Economic Panel (SOEP), ${ }^{5}$ for Italy the 2008 Survey of Household Income and Wealth (SHIW), for Luxembourg from the 2007 wealth module of the PSELL-3/EU-SILC, for Spain from the 2008 EFF and the data for the United States come from the 2007 Survey of Consumer Finances (SCF).

The data contain detailed information on multiple income sources and financial and nonfinancial assets and debts. On the basis of this detailed information, we use the conceptual framework developed by the Luxembourg Wealth Study (described in Sierminska et al. (2006)) for creating harmonized variables of net worth (total assets: financial assets, principal residence, investment real estate and business equity minus liabilities: mortgages and non-housing debt) and income. ${ }^{6}$ The data are collected at the household level and individual level variables that are reported (such as age, gender, education) refer to the respondent/household head. In most cases, this person is the person most knowledgeable about household finances.

\footnotetext{
${ }^{4}$ One exception is Italy which registers a small decrease in GDP per capita in 2008, the year of data collection.

${ }^{5}$ See Wagner et al. (2007) for details on the German survey.

${ }^{6}$ In the descriptive results (Table 3), each of the wealth variables have been bottom and top coded at their $1 \%$ and $99 \%$ levels to stop outliers from over-influencing our results. Our monetary variables have been converted to 2007 USD using PPP and price indices.
} 
Wealth (or net worth) is defined as assets less liabilities, where assets are composed of financial and non-financial assets. The components of wealth that we pay particular attention to in this study are total financial assets (which comprise deposit account, bonds, stocks, mutual funds, etc); principal residence, which equates to owner-occupied housing; investment real estate, which is composed of all residential and corporate real estate besides the principal residence and, on the liabilities side, mortgage debt which can relate to the principal residence or to investment real estate and, finally, non-housing debt.

As in all cross-country studies, we face the issue of data comparability and, while our conceptual framework carefully aligns the most comparable components across countries, some differences among the surveys remain. Table A.1 gives an idea of the measurement differences that could arise due to varying collection methods. For example, financial assets are created for the most part by aggregating the individual components (deposit accounts, risky assets). In Germany and Luxembourg this is not the case. Only the total balance is collected ${ }^{7}$. We consider these differences when interpreting our results.

In addition, we compare participation rates in the main assets and liabilities to two other data sources. Firstly, we compare the European countries in our harmonized database to the first wave of the Household Finance and Consumption Survey (HFCS). The HFCS data is collected in 2009-2010 which is slightly later than the data we use and the crisis may have had an impact on wealth portfolios in the meantime. However, we find that for the comparable instruments, principle residence, investment real estate, mortgage holdings and non-housing debt, participation rates in these four instruments are within 5ppt points of each other in both datasets (HFCN (2013)). Reported Financial Assets show greater differences with Germany, Italy and Luxembourg holding much lower levels of Financial Assets in our harmonized datasets than in the HFCS. In part this is due to the collection method, as shown in Table A.1, for Germany and Luxembourg and due to the fact that the HFCS data is multiply imputed for Italy while we rely on the simple imputation performed for the public use data by the Bank of Italy. For this reason, in our analysis we report total financial assets, but take account of these differences in the interpretation of our results and focus on a subgroup of financial assets, risky assets (stocks, bonds and mutual funds), which does not suffer from these survey-related measurement errors. Our second benchmark for checking the reliability of reported wealth holdings in our harmonized data is to compare our results for households in which the head is over 50 years of age with households in the Health and Retirement Study (HRS) in the US and the Survey of Health, Ageing and Retirement (SHARE) in Europe. Comparing our over50 participation rates in comparable instruments (Principle Residence and Mortgage) to

\footnotetext{
${ }^{7}$ In Germany, deposit accounts are not included in the aggregate, while in Luxembourg information is collected in brackets and then imputed
} 
those reported in (Christelis et al. (2012)), who use the HRS and SHARE datasets, we find discrepancies of less than 4ppt. We, therefore, feel confident that our harmonized dataset is broadly representative of wealth participation rates in the countries examined. In this paper, we ultimately focus on the younger cohort and draw comparisons with more mature household.

\section{Methodology}

The participation decision is the decision to hold or not to hold a particular asset or liability. The participation rates for each asset/liability are shown in Table 2, while mean asset levels are in Table 3 . There is quite a bit of cross-country variation in the decision to hold assets, as well as liabilities. Among financial assets, risky assets (which include stocks, bonds, and mutual funds) are particularly different. In the US, the share of people investing in this type of asset is the highest, followed by Canada. Large differences are also observed for debt. Italy has the lowest participation in debt followed by Germany, Luxembourg, Spain, Canada and the US.

The sample in both tables is further partitioned by age to highlight cohort differences in portfolio composition. The largest age differences are seen for homeownership, housing and non-housing debt. Younger households are less likely to own their home and are more likely to have debt compared to more mature households (shown in the bottom panel of Table 2). In a comparison across countries, we find smaller differences in participation rates among the young than among the elderly. In fact, the portfolio participation rates in the United States and Canada are almost the same for the younger cohort, apart from some minor differences in business ownership and risky asset take up.

There is a strong relationship between income and participation in both assets and liabilities. Past research shows a variation in holdings of particular assets across the distribution with higher income households holding a large share of risky assets (e.g. Carroll (2002)). We can also confirm that there is cross country variation in these trends. As we plot participation rates by income percentiles (Figure 1), we find that ownership rates of assets and liabilities rise as we move up the income distribution, but there are also noticeable cross country differences. For example, there is large cross-country variation at the top of the distribution in risky asset ownership, with the US having the highest participation in our sample of countries. For debt there seem to be 2 groups: the higher debt countries (Canada, Luxembourg and the US) and lower debt holdings (Germany, Italy, Spain). Spain has higher real estate ownership than every other country, particularly at the bottom 
of the income distribution while Germany is a low homeownership country.

Since substantial differences in asset participation by income level exist across countries, as a next step, we investigate whether there are other significant drivers of these ownership differences. These differences could be driven by differences in population characteristics between countries (such as household structure, education, the labor market) or could be a result of differences between countries that are more difficult to measure and capture in a regression, including institutional and cultural differences, for example. A suitable way to examine these differences is to make use of an extension of the Blinder-Oaxaca nonlinear decomposition for binary variables, elaborated by Fairlie $(1999,2005)$

We estimate a logit model for participation in a particular wealth component $w$ :

$$
p_{j}(w)=F(X \beta)
$$

and examine the differences between country $j$ and our reference country, in this case the U.S. $(j=u s)$ :

$$
\hat{p}^{u s}(w)-\hat{p}^{j}(w)=\left(\hat{p}^{u s}(w)-\hat{p}_{j}^{u s}(w)\right)+\left(\hat{p}_{j}^{u s}(w)-\hat{p}^{j}(w)\right)
$$

where $\hat{p}_{j}^{u s}(w)$ is the counterfactual participation rate of households in country $j$ if faced with U.S. institutional features and other unobservables, given the distribution of characteristics $X$ in country $j$. The first expression on the right hand side of equation 2 represents differences in participation due to characteristics, i.e., to differences in the distribution of $X$ between the U.S. and country $j$. The second term represents differences due to differences in the group processes determining the decision to own or not to own a particular asset. This unexplained effect can be attributed to different cross-country risk preferences, cultural differences, institutional differences and other unobservables across countries. For simplicity, we refer to it as the unexplained or institutional effect.

The characteristic gap is the estimation of the total contribution of the whole set of observed characteristics to the country gap in participation. We would like to know the contribution of each specific characteristic since it is likely that they have varying and, sometimes, opposing effects. Thus, in order to identify the contribution of specific factors, we break $X$ down into sets of characteristics: $X_{L}$ (labor market characteristics), $X_{E}$ (education characteristics), $X_{D}$ (demographic characteristics), $X_{M}$ (marital status), $X_{I}$ (income) and $X_{W}$ (the level of other wealth). Taking a simple example, assume that 
$X=X_{L}+X_{D}$. We can express the independent contribution of $X_{L}$ to the gap as:

$$
\frac{1}{N} \sum_{i=1}^{N}\left[F\left(X_{L i}^{u s} \beta_{L}^{u s}+X_{D i}^{u s} \beta_{D}^{u s}\right)-F\left(X_{L i}^{j} \beta_{L}^{u s}+X_{D i}^{u s} \beta_{D}^{u s}\right)\right]
$$

For example, imagine that stock ownership is encouraged via employer company incentive plans. In this case, different employment levels between the US and country $j$ may explain a portion of the difference in stock market participation between these two countries. This effect will be captured in the overall characteristic effect but can also be isolated from the effect of other characteristics using equation 3. Now, imagine that company incentive plans differ across countries. This will be an institutional difference that will be part of the unexplained difference in cross-country stock market participation levels. ${ }^{8}$

\section{Results}

\subsection{Country differences in asset participation}

In order to identify the determinants of holding a particular asset we estimate several logit specifications for each country. We present the results for the one with the best fit. The coefficient estimates are used to determine whether there are country differences in the decision to hold particular assets and to calculate the contribution of country differences in household characteristics to the country differences in asset participation.

The dependent variable is equal to one if the household holds the asset in question and is equal to zero otherwise. We include a number of variables, which have been shown to affect participation in wealth. These include a set of demographic variables: age, the presence of children under 18 and a set of marital status variables which consist of indicator variables for married and divorced. Out of these we create family types: singles, single-parents, couple without kids and couples with kids. We also include gender, education variables which have been harmonized across countries ${ }^{9}$ and labor market variables, which include indicators for employment, self-employment and retirement for the older population. Finally, we include income and wealth levels not pertaining to the asset in question, transformed using the inverse hyperbolic sine. ${ }^{10}$

\footnotetext{
${ }^{8}$ Isolating its contribution to the unexplained effect is beyond the scope of this study.

${ }^{9}$ Low education indicates less than high school, medium education represents completed high school and high education indicates completed university

${ }^{10}$ We experiment with various specification of the monetary variables including levels and log transfor-
} 
In a comprehensive study of household portfolios, Guiso et al. (2003) estimate the participation decision for selected assets on a common set of explanatory variables. The results for the US indicate that the ownership of almost all types of assets and liabilities rises with other wealth (except credit card balances and non-housing debt). And as wealth rises, the share of total assets held in homes and other non-financial assets declines, while the share in risky assets and investment real estate rises. This is also true for each of the countries that we study as we observe a positive effect of other wealth on the participation decision of each of the assets examined (see Table A.3 and A.4). However, we find no conclusive evidence that the effect is larger for risky assets and investment real estate than for principal residence and financial assets in our sample countries.

Given that risk preference vary with age, we typically expect higher ownership of risky assets among older cohorts. Younger people face more background risk, which affects their preference for risky assets. As their uncertainty about lifetime income declines and they enter their prime-age years they may be willing to take on more risk. Older people, on the other hand, exhibit less labor supply flexibility compared to younger people. The latter can work more or retire later if they have low returns to their investments, the elderly are left to rely on the retirement income. We find some evidence, looking at the marginal effects of the 50+ households (not shown), that participation in risky assets increases with age.

Education is generally positively correlated with income and, hence, with asset holdings. Education may also be correlated with financial literacy (van Rooij et al. (2011)), with the more educated being more financially savvy. We find that education increases participation in financial assets, risky assets and investment real estate for each country in our sample. We also find that it increases mortgage participation, except in Canada and Luxembourg.

Another important explanatory characteristic can be household composition. For example, Bover (2010) find this to be important in explaining a lot of the observed differences in the wealth distribution between the US and Spain. Other research indicates that married couples are generally better off and differences by family type are stronger than by gender (Bover (2010); Sedo and Kossoudji (2004) for housing; Yamokoski and Keister (2006) for wealth levels). We find that family types have higher explanatory power than marital status. In addition, since there exist strong age effects in portfolio composition, we interact household types with age. We find the the age-family-type effects can sometimes be of opposite sign so that separating them by age cohort gives us more information. In Table A.3, we find that family types matter for the homeownership decision. Couples mation, but find the inverse hyperbolic sine transformation to yield the best fit. 
with children are more likely to own their home than singles or couples without children, particularly in the US, Canada and Germany. Single parents are also less likely to hold financial assets. This can be caused by two things. First, children generally lead a household to incur higher expenses. Second, there is a higher probability of owning nonfinancial assets in households with children. In terms of debt, we find that as households age, they are more likely to have a mortgage, regardless of family type.

Figure 1 shows that the correlation between income and participation varies across countries. From Tables A.3 and A.4, we see that the marginal effect of income is generally positive and significant for homeownership and risky assets. For investment real estate it only matters in the US while for financial assets, it is not significant in Italy and Spain, where family gifts or bequests may play a greater role.

\subsection{Decomposition of the Participation Decision}

In our decomposition we focus on the assets and liabilities which constitute the main part of the portfolio: homeownership, investment real estate ownership and mortgage holding. For a subset of countries we are also able to compare the effects for financial assets, risky assets and non-housing debt. We group the possible explanatory factors that can affect asset ownership. Demographics include family types (single, single parents, couples without children and couples with children) interacted with 3 age groups (under 30, 30-39 and 40-49). Education is composed of indicator variables for low and high education. The labor market group includes indicator variables for employed, self-employed and retired. We also include income and wealth separately. The results for the decompositions can be found in Tables 4 and 5 for principal residence, investment real estate, debt and financial assets. We use the specification from the estimation shown in Tables A.3 to A.4 for households whose head is under 50 years of age.

Overall, we find that country differences in variables such as education, demographics and income provide significant contributions to the wealth participation gap. The unexplained part of the gap varies across countries and asset types. These differences may be partly caused by differences in institutions, but also by important unmeasurable factors such as, for example, risk preferences.

In each of the panels in tables 4 and 5, the top section reports estimates of the contribution of country differences in specific observable groups of variables to the explained portion of the participation gap. In the second panel, the probability of holding the asset in the base country (the U.S.) $P(x=0)$ and the reference country $P(x=1)$ is reported. Next, 
Diff indicates the raw participation gap, Exp refers to the explained gap (due to characteristics) and Unexp the unexplained gap (due to institutions or culture). In the adjacent column, for each country we show the percentage each set of characteristics contributes to the explained gap and, below this, we report the ratio of the explained and unexplained gaps to the base participation in the U.S.

For example, looking at let top left panel of Table 4, we see that $62.6 \%$ of U.S. households and $59.6 \%$ of Canadian households own their principal residence. $29 \%$ less Canadian households own their own home than U.S. households for explained reasons (this corresponds to a 18ppt counterfactual gap in homeownership if the institutional setting in Canada was identical to that in the U.S.). This explained gap is largely due to differences in income between Canadian and U.S. households (as evidenced by the $71 \%$ contribution of this variable to the explained gap). The unexplained gap is $-24 \%$ meaning that, if Canadian households were like U.S. households in their characteristics - in this case, that would mainly require a convergence of their income levels to U.S. levels - $24 \%$ more Canadian households would own their own home than U.S. households. This gap can be attributed to different institutional or cultural features of the two countries. So, to summarize, this decomposition tells us that, while U.S. households own their own home more often than Canadian households, this gap would be even larger were it not for institutional or other differences between the two countries which encourage Canadian households to buy their own home.

Principal residence First, we examine real estate. U.S. households are more likely to own their main residence than those in Canada, Germany and Italy while the opposite is true in Luxembourg and Spain. Raw participation gaps are small except in Germany (31 ppt), which has traditionally had very low homeownership rates and Spain (-14 ppt) which has quite high homeownership rates. However, in the case of Canada, Spain and Italy, the small raw participation gaps mask larger explained and unexplained gaps which work in opposite directions. In each of the countries except Luxembourg, the characteristics of U.S. households, mainly income and household composition, lead them to have higher homeownership rates. In terms of household composition, the contribution of the two older household categories (30-39 and 40-49 years old) is higher than that of the youngest category (20-29 years old). This indicates that it is cross-country differences in the composition of this group of households, (the 30-49 year olds) that explain most of the explained demographic participation gap. In Canada, Italy and Spain, the unexplained gaps are negative, indicating that these countries would have higher homeownership rates if their households' characteristics were the same as those in the U.S. Only in Germany is there a large positive unexplained gap which reflects this country's traditionally low 
homeownership rates for reasons unrelated to household characteristics.

Investment real estate The U.S. has a higher participation in investment real estate than Canada and Germany while Italian, Luxembourgish and Spanish households have higher investment real estate ownership than the U.S. However, for each country there is a large positive explained gap in participation rates, meaning that U.S. households have characteristics which lead them to hold more investment real estate than each of the other countries. Again, most of the explained differences are due to income although virtually all of the other variable groups except other wealth also play a role. The unexplained gap is large and negative in each country and is largest in Spain. If the European and Canadian households were the same as those in the U.S. in terms of characteristics, their participation in investment real estate would be around 50\% higher due to the institutional and cultural setting. So, while investment real estate ownership is higher in the U.S. than in Canada and Germany, this is explained by U.S. household characteristics. The institutional effect works in the opposite direction, deterring similar U.S. households from holding investment real estate compared to Canada or the European countries.

Debt In terms of debt, large differences can be observed across countries. The U.S. has higher participation in debt than any of the other countries examined (both for mortgages and non-housing debt). This difference is particularly large in the European countries where the unexplained and explained gaps are generally both positive (Germany, Italy and Spain), indicating that European countries participate less in debt than the U.S. both for reasons related to household characteristics and for institutional reasons. For example, the largest differences in the take-up rate of mortgage is between the U.S. and Italy (32.7ppt), Germany (30.5ppt) and then Spain (10.1ppt). The gap between US mortgage participation and Luxembourg mortgage participation is very small. The large explained gaps in mortgage participation between the U.S. and Europe are explained in large part by cross-country income differences although unexplained gaps are also large. There is a similar patter for non-housing debt but, here, the role of explanatory variables is smaller than in the case of mortgage. The majority of the gap in non-housing debt participation between the U.S. and the European countries is unexplained while the gap between the U.S. and Canada is very small.

Financial Assets As discussed in Section 2, our conclusions regarding financial assets relate to the sub-sample of countries for which the data are most reliable, i.e. the US, Canada and Spain. The U.S. has higher participation in financial assets than both of these 
countries. However, the participation gaps are small and partly explained by income, demographics and education such that the unexplained component is negligible. In each country except Spain, the unexplained gap is positive indicating that households in these countries hold less financial assets due to institutional features.

For some countries, where data availability allows, we are also able to examine risky assets. The US has the highest participation rate in this instrument. The smallest participation gap is observed for Canada (7.7ppt), followed by Italy (16.1ppt) and Spain (30.1ppt). In Canada, the gap is mostly explained by monetary factors: differences in income and wealth. However, in Europe, education plays at least as important a role as income. Education differences (noted in Table A.5) are responsible for much of the explained difference in participation in risky assets between the US and Europe.

Cohort effects The findings presented above have been estimated for the population under 50. However, portfolio choice is affected by age and cohort effects. In fact, one of the limitations of cohort specific data is the lack of insight into age differences in the drivers of wealth portfolio choices. Meanwhile, there are reasons to believe that the role of household characteristics will have a varying effect on their willingness to purchase assets and take up loans over their life-span. For example, a new graduate with a fulltime job could potentially have a much easier time purchasing a home in a country with easier credit regulations (for example, where a lower down payment is required). For an older individual, with an established credit history, these regulations may not be as much of an issue and the portfolio decision could depend on other factors, for example, their family structure. As a result, we perform the same analysis for households headed by a person above 50 years old. ${ }^{11}$ In terms of explained participation gaps, income is the main driver for the younger cohort while a range of variables and, education in particular, drive the explained participation gaps for the older cohort. Liquidity constraints may be more binding for the younger cohort who lack an earnings history and/or collateral so this is unsurprising and is true across countries.

We find that, for principal residence and investment real estate, the younger cohort has larger unexplained participation gaps with the U.S., compared to the older cohort. This is shown in Table 6. This indicates that institutions may have more effect on the asset participation decisions of younger households than older households. The inverse is true for debt. Cross-country institutional differences influence the debt participation of the older cohort more than that of the younger cohort, for whom characteristics drive more of the cross-country debt participation gaps. One prominent example that comes to mind here

\footnotetext{
${ }^{11}$ The results can be found in tables A.6 and A.7.
} 
is opportunities for older cohorts to smooth their consumption via borrowing in order to supplement their retirement income or due to educational expenditures for their children. The explained and unexplained gaps between US and European/Canadian participation in financial and risky asssets are largely the same across cohorts.

Thus, a focus on the over-50 population, present in previous studies, may lead to an underestimation of the role of demographic differences, particularly income, in explaining many portfolio component differences across countries. Institutional differences (investigated below) appear to be more important for the younger cohort's asset and the older cohort's debt participation decision. This is an important finding as the younger cohort's asset participation decision and the older cohort's debt participation decision may be more responsive to policy instruments while the younger cohort may react more to changes in their own personal circumstances (for example, loss of income or job during the financial crisis).

\subsection{The role of institutions}

In this section, we take a more in-depth look at institutional differences in the countries in our sample and try to draw a link between the sign and magnitude of the unexplained (institutional) gaps in wealth participation across countries and the institutional setting. This is by no means and easy task given that we have a small sample of countries, but we are able to find some consistent patterns. We run bivariate linear regressions of the unexplained participation gap for each component of wealth on institutional features of each country. We would like to perform a more sophisticated analysis of the link between institutions and the unexplained wealth participation gap but, for this, more data points would be needed.

In our analysis, we use eight indices summarized in Table 7 . Their possible effect on investment decisions is discussed below. Four of these directly relate to the economy. The first, the Financial Development Index, is a score for the breadth, depth and efficiency of each country's financial system and capital markets (Bilodeau (2008)). Next, the Index of Economic Freedom, measures the economic freedom in each country, with higher scores indicating lower government interference in the economy (Kane (2007)). The banking regulation index measures the degree of banking regulation in each country, including enforcement power (Andrews et al. (2011)). Lastly, the marginal tax rate measures the tax due on an extra dollar of income.

We also use three features of mortgages in each country (see Andrews et al. (2011)): 
the maximum loan-to-value (LTV) ratio, the prevalence of fixed rate mortgages and the typical maturity rate of mortgages in each country. Lastly, we use a measure of mathematical literacy from the PISA project as a proxy for the education system. We expect that these institutional and country specific indicators will help to shed some light on different cross-country investment patterns that cannot be explained by household characteristics.

The results of these simple regressions are depicted in Table 8 and Figures A.1 to A.4 for four components of the wealth portfolio. We exclude Financial Assets from this analysis, as it is difficult to interpret the relationship between financial assets held in different types of account and these institutions. In addition, as explained in Section 2, the unexplained gap in financial asset participation for some countries may capture differences in data collection methods. This is not the case for the other components of the wealth portfolio. We also exclude Risky Assets from this analysis as we do not have information on this wealth component in either Germany or Luxembourg and we consider four data points to be too few for this analysis.

The dependent variable is the unexplained participation gap in each component of the wealth portfolio in turn. These gaps are summarized in Table 6 and measure the percentage difference between each countries participation rate and the US participation rate, which is not explained by household characteristics:

$$
\hat{p}_{j}^{u s}(w)-\hat{p}^{j}(w)
$$

For the purpose of this exercise and to facilitate interpretation, we multiply this gap by -1 . That is, we define:

$$
g \hat{a} p=\hat{p}^{j}(w)-\hat{p}_{j}^{u s}(w)
$$

and use this definition of the unexplained gap, gâp as our dependent variable. Our simple model becomes:

$$
g \hat{a} p=\alpha+\beta I
$$

where $I$ takes the value of each of the institutional indices in turn. We represent the gaps in this way in this section so that the U.S. always has a 0 unexplained gap and a positive unexplained gap for the other countries means that similar households in that country have higher participation rates that those in the U.S. Hence, a positive slope in figures Figures A.1 to A.4 implies a positive correlation between the unexplained gap and the institutional index and, therefore, a positive correlation between participation in that particular wealth component and the institutional index in that country. Likewise, a positive coefficient in Table 8 indicates a positive correlation between participation in that particular wealth 
component and the institutional index. We summarize the results by index below.

Financial Development This index measures the breadth, depth and efficiency of each country's financial system across a range of factors including the institutional environment, financial stability, banking and non-banking financial services, financial markets and financial access. As such, we expect more financially developed countries to provide higher access to credit through a more stable, accessible and efficient financial system. This is indeed what we observe in Table 8 and Figures A.1 to A.4. Regressing the unexplained participation gap in mortgages and in non-housing debt on this index yields positive coefficients both for households under 50 years of age and over. We also observe a negative coefficient on this index when the dependent variable is either form of housing. It is possible that countries with more developed and stable financial systems substite real estate investment for investment in more liquid financial assets. Financial development, therefore, seems to be negatively associated with homeownsership and positively associated with holding debt.

Economic Freedom We observe similar patterns with the index of Economic Freedom. Economic Freedom measures the degree of government interference in each economy and captures business freedom, trade freedom, fiscal freedom, freedom from government, monetary freedom, investment freedom, financial freedom, property rights freedom, freedom from corruption and labor freedom. The higher this index is, the less the government interferes in the economy. As such, we might expect more economically free countries to provide less subsidies for housing and to regulate bank lending less. Our results confirm these theories with economic freedom associated with less investment in housing and higher debt holding, especially non-housing debt.

Bank Regulation Banking regulation measures the degree of banking regulation, including enforcement power, in each country. We expect that countries with higher levels of bank regulation will have stricter lending policies but, also, more banking stability. This may lead to higher trust in institutions. We observe that the degree of regulation is positively correlated with the propensity to hold debt (except for mortgage debt among the under-50 population) which is in line with the idea that more regulation promotes lending through its effect on stability rather than hindering it through its effect on regulatory capital adequacy ratios and loan to value measures. We also observe a negative correlation between holding investment real estate and the degree of banking regulation which could indicate that lending for this purpose is curtailed in more regulated banking systems or 
that higher trust in institutions encourages households to invest in financial products more than in real estate.

Marginal Tax Rate The marginal tax rate measures the tax due on an extra dollar of income for a one earner household with two children where the principal earner earns the average wage. Higher marginal tax rates indicate less disposable income and less incentive to earn investment income as more of it will have to be paid over in tax. Intuitively, we find a negative association between the marginal tax rate and homeownership, particularly investment real estate.

Mortgage Characteristics We use three measures relating to mortgages in each country: the typical maturity length, the prevalence of fixed rate mortgages and the maximum loan-to-value ratio. We find that longer mortgage maturities, higher likelihoods of getting a fixed rate mortgage and higher regulatory loan-to-value ratios are associated with higher rates of debt-holding. That is, the lower the initial downpayment (through a higher loan-to-value ratio), the lower the monthly repayments (through longer mortgage terms) and the less risk that is associated with the loan (through fixed rate mortgages), the more likely households are to hold debt.

Mathematical literacy We use a measure of mathematical literacy from the 2006 PISA test which evaluates the mathematical literacy of 15 year olds across countries in a harmonized way. Financial literacy has been found to be negatively associated with non-housing debt (Lusardi and Tufano (2009)) and positively associated with mortgage participation (Brown and Graf (2012)). We find a positive association between mathematical literacy and both types of debt, particularly for younger households, although the magnitude of each of these effects is small, overall.

\section{Conclusions}

In this paper, we apply techniques novel to the analysis of wealth portfolios to new and harmonized wealth data. We decompose the household participation decision for a selection of assets and liabilities across countries, focusing on households whose head is under 50 years of age and comparing these results to those over 50 years old.

In terms of the wealth participation decision we find that US households are, generally, 
more likely to own housing than Canadian/European households. This is due to their household characteristics (demographics and income) so similar households in Canada and Europe (except Germany) actually hold more real estate than US ones and this difference could be attributable to the institutional setting. A closer look at household differences between countries indicates that European households tend to buy houses later in life than in the US. Debt participation is higher in the US than in Canada/Europe, particularly mortgage participation. For mortgage participation, these differences are mainly explained by income, demographics and education. For other debt, differences are largely unexplained and could also be due to institutional differences between the US, Canada and Europe. There are small participation gaps in financial assets across countries although, looking at the sub-category of risky assets, the US has much higher participation that the other countries examined. These differences are mainly explained by income in Canada and by income and education in Europe. There is a large unexplained gap only in Spain.

Where we find significant explained participation gaps, they are mainly explained by income and household composition differences for young households. Education and household composition drive the explained gaps for older households. For the young, asset participation differences are more "unexplained" and likely to be influenced by institutions while for the older households, debt participation differences across countries are more "unexplained" and susceptible to be influenced by institutions. These are important findings as they indicate that the younger cohort's wealth participation is more vulnerable to income shocks (such as those suffered during the great recession) and is more susceptible to be influenced by policies encouraging investment in assets. For the older cohort, which may have more trouble smoothing consumption through retirement, there is scope for policies that encourage debt holding using assets as collateral e.g. reverse mortgages.

Experimenting with a selection of institutional indicators to attempt to discover why identical households in different countries invest differently, we find institutions to affect decisions in the way we would expect. In more financially developed and economically open countries, households are less likely to own housing but more likely to be in debt. Higher marginal tax rates are associated with lower investment in housing. Typical mortgage characteristics and mathematical literacy are also found to be linked to the level of debt holding. There is a bigger link between debt and institutions for the old, confirming that the large unexplained debt participation gaps for this cohort are likely to be at least partly linked to institutions. We find a similar link between assets and institutions for the young and the old. Overall, the institutional features we study seem to encourage European households, particularly mature ones, to participate in real estate while discouraging them from mortgage use. Looking into the future, this has potentially negative consequences for the elderly population as they may find it difficult to cash-out equity from 
their home to help finance their retirement

This paper has focused on the participation decision in wealth, without reference to the level of investment, given participation. This, obviously, is another important aspect of wealth portfolios and deserves attention in future literature. With the development of additional data sources, which contain adequately detailed information, future research could also try to control for observable institutional factors using instrumental variables or other techniques to tease out the causal link between institutions and wealth participation across countries. 


\section{References}

Andrews, D., Sánchez, A. C., and Åsa Johansson (2011). Housing markets and structural policies in oecd countries. OECD Economics Department Working Papers 836, OECD Publishing. 13

Bilodeau, J., editor (2008). The Financial Development Report 2008. World Economic Forum,. 13

Bover, O. (2010). Wealth Inequality and Household Structure: U.S. vs. Spain. Review of Income and Wealth, 56(2):259-290. 8

Bover, O., Casado, J. M., Costa, S., Caju, P. D., McCarthy, Y., Sierminska, E., Tzamourani, P., Villanueva, E., and Zavadil, T. (2013). The distribution of debt across euro area countries. Working Paper. 2

Brown, M. and Graf, R. (2012). Financial literacy, household investment and household debt: Evidence from switzerland. Working Papers on Finance 1301, University of St. Gallen, School of Finance. 16

Campbell, J. Y. (2006). Household finance. The Journal of Finance, 61(4):1553-1604. 1

Carroll, C. (2002). Household Portfolios, chapter Portfolios of the RIch. The MIT Press. 5

Chiuri, M. and Jappelli, T. (2010). Do the elderly reduce housing equity? an international comparison. Journal of Population Economics, 23(2):643-663. 1

Christelis, D., Georgarakos, D., and Haliassos, M. (2012). Differences in portfolios across countries: Economic environment or household characteristics? The Review of Economics and Statistics, (forthcoming). 1, 2, 5

Crook, J. and Hochguertel, S. (2007). US and European Household Debt and Credit Constraints. Discussion Paper 2007-087/3, TInbergen Institute. 1

Fairlie, R. W. (1999). The Absence of the African-American Owned Business: An Analysis of the Dynamics of Self-Employment. Journal of Labor Economics, 17(1):80-108. 6

Fairlie, R. W. (2005). An Extension of the Blinder-Oaxaca Decomposition Technique to Logit and Probit Models. Journal of Economic and Social Measurement, 30(4):305316. 6 
Gornick, J. C., Sierminska, E., and Smeeding, T. M. (2009). The income and wealth packages of older women in cross-national perspective. The Journals of Gerontology: Social Sciences, Volume 64B, Number 3, May 2009:402-414. 1

Guiso, L., Haliassos, M., and Jappelli, T. (2003). Household stockholding in Europe: where do we stand and where do we go? Economic Policy, 18(36):123-170. 1, 8

HFCN (2013). The eurosystem household finance and consumption survey. results from the first wave. Technical report, European Central Bank. 4

Kane, T. (2007). 2007 Index of Economic Freedom. Washington, D.C. and New York: Heritage oundation and the Wall street Journal. 13

Lusardi, A. and Tufano, P. (2009). Debt literacy, financial experiences, and overindebtedness. NBER Working Papers 14808, National Bureau of Economic Research, Inc. 16

Sedo, S. A. and Kossoudji, S. A. (2004). Rooms of One's Own: Gender, Race and Home Ownership as Wealth Accumulation in the United States. IZA Discussion Papers 1397, Institute for the Study of Labor (IZA). 8

Sierminska, E., Brandolini, A., and Smeeding, T. (2006). The Luxembourg Wealth Study: A cross-country comparable database for household wealth research. Journal of Economic Inequality, 4(3):375-383. 3

Sierminska, E. M., Frick, J. R., and Grabka, M. M. (2010). Examining the gender wealth gap. Oxford Economic Papers, 62(4):669-690. 2

van Rooij, M., Lusardi, A., and Alessie, R. (2011). Financial literacy and stock market participation. Journal of Financial Economics, 101(2):449 - 472. 8

Wagner, G. G., Frick, J. R., and Schupp, J. (2007). The German Socio-Economic Panel Study (SOEP) - Scope, Evolution and Enhancements. Schmollers Jahrbuch, 127 (1):139-169. 3

Yamokoski, A. and Keister, L. (2006). The wealth of single women: Marital status and parenthood in the asset accumulation of young baby boomers in the united states. Feminist Economics, 12(1-2):167-194. 8 


\section{Tables and Figures}

Table 1: Country sample macroeconomic conditions.

\begin{tabular}{|c|c|c|c|c|c|c|c|c|}
\hline \multicolumn{9}{|c|}{ A. Real GDP growth } \\
\hline & 2002 & 2003 & 2004 & 2005 & 2006 & 2007 & 2008 & 2009 \\
\hline Canada & 2.9 & 1.9 & 3.1 & 3.0 & 2.9 & 2.5 & 0.4 & -2.7 \\
\hline Germany & 0.0 & -0.2 & 0.7 & 0.9 & 3.4 & 2.6 & 1.0 & -4.9 \\
\hline Italy & 0.5 & 0.1 & 1.4 & 0.8 & 2.1 & 1.4 & -1.3 & -5.1 \\
\hline Luxembourg & 4.1 & 1.5 & 4.4 & 5.4 & 5.6 & 6.5 & 0.0 & -3.4 \\
\hline Spain & 2.7 & 3.1 & 3.3 & 3.6 & 4.0 & 3.6 & 0.9 & -3.6 \\
\hline United States & 1.8 & 2.5 & 3.6 & 3.1 & 2.7 & 2.1 & 0.4 & -2.4 \\
\hline \multicolumn{9}{|c|}{ B. Harmonised unemployment rates } \\
\hline & 2002 & 2003 & 2004 & 2005 & 2006 & 2007 & 2008 & 2009 \\
\hline Canada & 7.7 & 7.6 & 7.2 & 6.8 & 6.3 & 6.0 & 6.1 & 8.3 \\
\hline Germany & 8.4 & 9.3 & 9.8 & 10.6 & 9.8 & 8.4 & 7.3 & 7.5 \\
\hline Italy & 8.6 & 8.5 & 8.0 & 7.7 & 6.8 & 6.2 & 6.8 & 7.7 \\
\hline Luxembourg & 2.6 & 3.8 & 5.0 & 4.6 & 4.6 & 4.2 & 4.9 & 5.4 \\
\hline Spain & 11.1 & 11.1 & 10.6 & 9.2 & 8.5 & 8.3 & 11.4 & 18.0 \\
\hline United States & 5.8 & 6.0 & 5.5 & 5.1 & 4.6 & 4.6 & 5.8 & 9.3 \\
\hline \multicolumn{9}{|c|}{ Source: OECD (2010), Annex Tables 1 and 14} \\
\hline
\end{tabular}


Table 2: Portfolios participation rates for the whole population, 25 to 49 years olds and 50 and over.

\begin{tabular}{|c|c|c|c|c|c|c|c|}
\hline All & US & Canada & Germany & Italy & Luxembourg & Spain & Total \\
\hline Total Fin.Assets & 94.29 & 88.50 & 57.65 & 77.08 & 67.82 & 92.95 & 73.11 \\
\hline Deposit Accounts & 92.70 & 87.00 & na & 76.48 & na & 92.95 & 41.39 \\
\hline Risky Assets & 34.22 & 26.55 & na & 21.15 & na & 3.37 & 13.14 \\
\hline Main Residence & 71.86 & 65.47 & 41.15 & 70.25 & 71.03 & 83.10 & 55.57 \\
\hline Other Property & 19.99 & 16.75 & 13.21 & 22.02 & 27.84 & 36.43 & 17.17 \\
\hline Business Equity & 12.57 & 17.18 & 6.14 & 16.78 & 5.64 & 12.25 & 9.53 \\
\hline Total assets & 95.46 & 94.44 & 71.52 & 91.20 & 88.55 & 98.33 & 82.40 \\
\hline Total Debt & 77.34 & 69.86 & 36.55 & 25.79 & 35.14 & 46.28 & 50.10 \\
\hline Mortgage & 48.30 & 35.95 & 18.45 & 12.71 & 35.14 & 26.05 & 28.34 \\
\hline Other Home Debt & 5.80 & 4.71 & 5.88 & na & na & 8.02 & 5.50 \\
\hline Non-housing debt & 66.47 & 56.99 & 21.08 & 15.59 & na & 23.20 & 36.09 \\
\hline 24 to 49 year olds & US & Canada & Germany & Italy & Luxembourg & Spain & Total \\
\hline Total Fin.Assets & 91.97 & 86.17 & 52.32 & 79.73 & 64.40 & 92.05 & 70.97 \\
\hline Deposit Accounts & 90.25 & 84.64 & na & 79.23 & na & 92.05 & 43.77 \\
\hline Risky Assets & 32.55 & 24.85 & na & 16.50 & na & 2.48 & 13.30 \\
\hline Main Residence & 62.61 & 59.59 & 32.02 & 57.66 & 64.09 & 77.00 & 47.52 \\
\hline Other Property & 15.46 & 14.39 & 10.31 & 15.95 & 21.48 & 29.19 & 13.56 \\
\hline Business Equity & 12.87 & 18.91 & 7.36 & 21.41 & 5.60 & 14.94 & 10.95 \\
\hline Total assets & 93.53 & 93.17 & 64.97 & 88.62 & 86.58 & 98.08 & 79.06 \\
\hline Total Debt & 86.56 & 81.86 & 50.36 & 40.64 & 53.91 & 66.61 & 64.34 \\
\hline Mortgage & 55.46 & 46.48 & 24.93 & 22.76 & 53.91 & 45.41 & 37.28 \\
\hline Other Home Debt & 6.21 & 4.98 & 5.62 & na & na & 10.05 & 5.67 \\
\hline Non-housing debt & 77.31 & 68.07 & 31.22 & 22.59 & na & 30.23 & 47.91 \\
\hline 50 and over & US & Canada & Germany & Italy & Luxembourg & Spain & Total \\
\hline Total Fin.Assets & 96.56 & 91.37 & 61.51 & 75.37 & 71.85 & 93.76 & 74.85 \\
\hline Deposit Accounts & 95.09 & 89.91 & na & 74.71 & na & 93.76 & 39.45 \\
\hline Risky Assets & 35.86 & 28.65 & na & 24.15 & na & 4.17 & 13.01 \\
\hline Main Residence & 80.93 & 72.71 & 47.78 & 78.38 & 78.40 & 88.53 & 62.13 \\
\hline Other Property & 24.43 & 19.66 & 15.31 & 25.94 & 34.97 & 42.89 & 20.12 \\
\hline Business Equity & 12.27 & 15.06 & 5.25 & 13.80 & 5.67 & 9.85 & 8.37 \\
\hline Total assets & 97.36 & 96.00 & 76.28 & 92.87 & 90.70 & 98.56 & 85.12 \\
\hline Total Debt & 68.31 & 55.08 & 26.53 & 16.21 & 14.95 & 28.14 & 38.50 \\
\hline Mortgage & 41.29 & 22.98 & 13.74 & 6.22 & 14.95 & 8.78 & 21.05 \\
\hline Other Home Debt & 5.40 & 4.38 & 6.07 & na & na & 6.20 & 5.37 \\
\hline Non-housing debt & 55.84 & 43.35 & 13.72 & 11.08 & na & 16.92 & 26.46 \\
\hline
\end{tabular}

Source: 2005 SFS, 2007 SCF, 2007 SOEP, 2008 SHIW, 2007 PSELL3 and 2008 EFF 
Table 3: Mean levels for the whole population, 25 to 49 years olds and 50 and over by country.

\begin{tabular}{|c|c|c|c|c|c|c|c|}
\hline & US & Canada & Germany & Italy & Luxembourg & Spain & Total \\
\hline Total Fin.Assets & 176,020 & 16,835 & 22,243 & 22,064 & 33,446 & 22,235 & 69,758 \\
\hline Deposit Accounts & 19,510 & 7,607 & na & 11,846 & na & 19,480 & 8,043 \\
\hline Risky Assets & 51,013 & 8,191 & na & 9,318 & na & 1,871 & 16,828 \\
\hline Main Residence & 206,655 & 68,364 & 101,139 & 188,389 & 381,255 & 227,195 & 145,330 \\
\hline Other Property & 56,090 & 11,790 & 27,318 & 38,578 & 126,962 & 94,656 & 39,910 \\
\hline Business Equity & 57,570 & 5,098 & 8,952 & 22,471 & 17,917 & 30,282 & 25,844 \\
\hline Total assets & 544,560 & 109,413 & 168,087 & 281,325 & 570,226 & 380,630 & 301,575 \\
\hline Total Debt & 96,811 & 26,838 & 31,016 & 10,381 & 48,678 & 36,704 & 50,190 \\
\hline Mortgage & 69,184 & 17,620 & 17,899 & 9,157 & 48,678 & 24,048 & 32,952 \\
\hline Other Home Debt & 7,649 & 2,176 & 6,924 & na & na & 8,434 & 6,566 \\
\hline Non-housing debt & 13,732 & 4,090 & 3,920 & 1,131 & na & 3,197 & 6,736 \\
\hline 24 to 49 year olds & US & Canada & Germany & Italy & Luxembourg & Spain & Total \\
\hline Total Fin.Assets & 92,840 & 8,843 & 13,081 & 15,073 & 24,520 & 15,902 & 40,455 \\
\hline Deposit Accounts & 13,334 & 3,747 & na & 9,632 & na & 14,627 & 6,018 \\
\hline Risky Assets & 22,800 & 4,978 & na & 5,081 & na & 1,010 & 8,360 \\
\hline Main Residence & 173,637 & 62,973 & 77,606 & 153,986 & 327,936 & 208,027 & 121,570 \\
\hline Other Property & 35,830 & 10,180 & 17,228 & 21,679 & 72,421 & 66,483 & 26,163 \\
\hline Business Equity & 43,288 & 4,953 & 9,547 & 26,321 & 18,473 & 30,233 & 22,932 \\
\hline Total assets & 367,063 & 92,916 & 124,171 & 223,285 & 453,052 & 323,897 & 222,651 \\
\hline Total Debt & 115,656 & 35,635 & 43,456 & 19,449 & 80,536 & 60,007 & 67,313 \\
\hline Mortgage & 85,549 & 24,778 & 29,174 & na & 80,536 & 43,400 & 47,390 \\
\hline Other Home Debt & 7,552 & 2,405 & 6,056 & na & na & 11,079 & 6,283 \\
\hline Non-housing debt & 17,353 & 5,101 & 5,577 & 1,701 & na & 3,954 & 9,255 \\
\hline 50 and over & US & Canada & Germany & Italy & Luxembourg & Spain & Total \\
\hline Total Fin.Assets & 257,549 & 26,678 & 28,895 & 26,576 & 43,125 & 27,884 & 93,642 \\
\hline Deposit Accounts & 25,564 & 12,361 & na & 13,276 & na & 23,808 & 9,695 \\
\hline Risky Assets & 78,667 & 12,149 & na & 12,054 & na & 2,639 & 23,730 \\
\hline Main Residence & 239,019 & 75,003 & 118,227 & 210,596 & 439,071 & 244,294 & 164,697 \\
\hline Other Property & 75,950 & 13,772 & 34,646 & 49,488 & 186,102 & 119,787 & 51,115 \\
\hline Business Equity & 71,568 & 5,277 & 8,520 & 19,985 & 17,314 & 30,325 & 28,218 \\
\hline Total assets & 718,537 & 129,732 & 199,975 & 318,791 & 697,280 & 431,238 & 365,904 \\
\hline Total Debt & 78,339 & 16,003 & 21,983 & 4,527 & 14,133 & 15,918 & 36,233 \\
\hline Mortgage & 53,144 & 8,804 & 9,712 & na & 14,133 & 6,786 & 21,183 \\
\hline Other Home Debt & 7,744 & 1,894 & 7,555 & na & na & 6,075 & 6,798 \\
\hline Non-housing debt & 10,184 & 2,844 & 2,718 & 762 & na & 2,521 & 4,682 \\
\hline
\end{tabular}

Source: 2005 SFS, 2007 SCF, 2007 SOEP, 2008 SHIW, 2007 PSELL3 and 2008 EFF Note: The levels are in 2007 Euros and include zeros. 
Table 4: Decomposition of portfolio participation decision for 25 to 49 year olds (Home, Investment Real Estate, and Debt.

\begin{tabular}{|c|c|c|c|c|c|c|c|c|c|c|}
\hline & $\begin{array}{c}\text { Canada } \\
\text { (1) }\end{array}$ & $\%$ & $\begin{array}{l}\text { Germany } \\
\text { (2) }\end{array}$ & $\%$ & $\begin{array}{l}\text { Italy } \\
(3)\end{array}$ & $\%$ & $\begin{array}{c}\text { Luxembourg } \\
\text { (4) }\end{array}$ & $\%$ & $\begin{array}{l}\text { Spain } \\
(5)\end{array}$ & $\%$ \\
\hline \multicolumn{11}{|c|}{ Principal Residence } \\
\hline sex & $0.004 *$ & 2 & $0.007 *$ & 6 & $0.003^{*}$ & 2 & $0.009 *$ & -25 & $0.008^{*}$ & 6 \\
\hline $\operatorname{demog} 1$ & $-0.006^{*}$ & -3 & 0.002 & 2 & $0.021 * * *$ & 17 & $0.007 * * *$ & -19 & $0.011 * * *$ & 8 \\
\hline $\operatorname{demog} 2$ & $0.061 * * *$ & 34 & $0.063 * * *$ & 52 & $0.047 * * *$ & 39 & $0.041 * * *$ & -113 & $0.023 * * *$ & 17 \\
\hline $\operatorname{demog} 3$ & $-0.024 * * *$ & -13 & $-0.049 * * *$ & -40 & $-0.090 * * *$ & -74 & $-0.063 * * *$ & 174 & $-0.058 * * *$ & -44 \\
\hline educ & $-0.002 * * *$ & -1 & $-0.006 * * *$ & -5 & $0.055^{* * *}$ & 45 & $0.026 * * *$ & -72 & $0.039 * * *$ & 30 \\
\hline LM & $0.004 * *$ & 2 & $0.013 * * *$ & 11 & -0.000 & 0 & $0.007 * * *$ & -19 & $0.018 * * *$ & 14 \\
\hline asini & $0.128 * * *$ & 71 & $0.088 * * *$ & 72 & $0.097 * * *$ & 80 & $-0.044 * * *$ & 121 & $0.102 * * *$ & 77 \\
\hline \multirow[t]{2}{*}{ asinwp } & $0.015 * * *$ & 8 & $0.003 * * *$ & 2 & $-0.012 * * *$ & -10 & $-0.019 * * *$ & 52 & $-0.011 * * *$ & -8 \\
\hline & & 100 & & 99 & & 100 & & 99 & & 100 \\
\hline$P(x=0)$ & 0.626 & & 0.626 & & 0.626 & & 0.626 & & 0.626 & \\
\hline $\mathrm{P}(\mathrm{x}=1)$ & 0.596 & & 0.320 & & 0.577 & & 0.641 & & 0.770 & \\
\hline Diff & 0.030 & & 0.306 & & 0.050 & & -0.015 & & -0.144 & \\
\hline Exp & 0.180 & 29 & 0.122 & 19 & 0.121 & 19 & -0.036 & -6 & 0.132 & 21 \\
\hline Unexp & -0.150 & -24 & 0.184 & 29 & -0.071 & -11 & 0.022 & 3 & -0.276 & -44 \\
\hline \multicolumn{11}{|c|}{ Investment Real Estate } \\
\hline sex & $0.006 * * *$ & 8 & $0.015 * * *$ & 23 & $0.004 * * *$ & 7 & $0.023 * * *$ & 54 & $0.019 * * *$ & 24 \\
\hline demog1 & -0.002 & -3 & 0.000 & 0 & 0.001 & 2 & -0.001 & -2 & 0.000 & 0 \\
\hline $\operatorname{demog} 2$ & -0.005 & -6 & -0.004 & -6 & -0.006 & -10 & -0.007 & -17 & $-0.013^{*}$ & -16 \\
\hline demog3 & $0.016 * *$ & 21 & 0.006 & 9 & 0.004 & 7 & 0.010 & 24 & 0.012 & 15 \\
\hline educ & $0.002 * *$ & 3 & $0.003 *$ & 5 & $0.020 * * *$ & 34 & $0.006^{* * *}$ & 14 & $0.012 * * *$ & 15 \\
\hline LM & $0.006 * * *$ & 8 & $0.004 * * *$ & 6 & $-0.013 * * *$ & -22 & $0.007 * * *$ & 17 & 0.001 & 1 \\
\hline asini & $0.053 * * *$ & 69 & $0.039 * * *$ & 59 & $0.049 * * *$ & 84 & $0.006 * * *$ & 14 & $0.048 * * *$ & 61 \\
\hline \multirow[t]{2}{*}{ asinwi } & 0.001 & 1 & $0.002 *$ & 3 & $-0.001 *$ & -2 & $-0.002 *$ & -5 & -0.001 & -1 \\
\hline & & 100 & & 99 & & 99 & & 99 & & 99 \\
\hline$P(x=0)$ & 0.155 & & 0.155 & & 0.155 & & 0.155 & & 0.155 & \\
\hline $\mathrm{P}(\mathrm{x}=1)$ & 0.144 & & 0.103 & & 0.160 & & 0.215 & & 0.292 & \\
\hline Diff & 0.011 & & 0.052 & & -0.005 & & -0.060 & & -0.137 & \\
\hline Exp & 0.077 & 50 & 0.066 & 42 & 0.059 & 38 & 0.042 & 27 & 0.079 & 51 \\
\hline Unexp & -0.067 & -43 & -0.014 & -9 & -0.064 & -41 & -0.103 & -66 & -0.216 & -139 \\
\hline \multicolumn{11}{|l|}{ Mortgage } \\
\hline sex & -0.003 & -2 & -0.005 & -4 & -0.002 & 0 & -0.007 & 25 & -0.006 & -4 \\
\hline demog1 & $-0.008^{*}$ & -4 & 0.002 & 2 & $0.019 * * *$ & 11 & $0.006 * * *$ & -21 & $0.010 * * *$ & 6 \\
\hline $\operatorname{demog} 2$ & $0.052 * * *$ & 29 & $0.057 * * *$ & 45 & $0.038 * * *$ & 21 & $0.035 * * *$ & -124 & $0.016^{* * *}$ & 10 \\
\hline demog3 & $-0.022 * * *$ & -12 & $-0.043^{* * *}$ & -34 & $-0.078 * * *$ & -44 & $-0.058 * * *$ & 206 & $-0.049 * * *$ & -29 \\
\hline educ & 0.000 & 0 & $-0.003^{* * *}$ & -2 & $0.077 * * *$ & 43 & $0.034 * * *$ & -121 & $0.053 * * *$ & 32 \\
\hline LM & $0.003 * * *$ & 2 & $0.013 * * *$ & 10 & 0.000 & 0 & $0.008 * * *$ & -28 & $0.017 * * *$ & 10 \\
\hline \multirow[t]{2}{*}{ asini } & $0.156^{* * *}$ & 87 & $0.106^{* * *}$ & 83 & $0.123 * * *$ & 69 & $-0.047 * * *$ & 167 & $0.126 * * *$ & 75 \\
\hline & & 99 & & 100 & & 100 & & 103 & & 99 \\
\hline $\mathrm{P}(\mathrm{x}=0)$ & 0.555 & & 0.555 & & 0.555 & & 0.555 & & 0.555 & \\
\hline $\mathrm{P}(\mathrm{x}=1)$ & 0.465 & & 0.249 & & 0.228 & & 0.539 & & 0.454 & \\
\hline Diff & 0.0898 & & 0.305 & & 0.327 & & 0.0156 & & 0.101 & \\
\hline Exp & 0.179 & 32 & 0.127 & 23 & 0.179 & 32 & -0.0282 & -5 & 0.168 & 30 \\
\hline Unexp & -0.089 & -16 & 0.178 & 32 & 0.148 & 27 & 0.044 & 8 & -0.067 & -12 \\
\hline \multicolumn{11}{|c|}{ Non-housing debt } \\
\hline $\operatorname{sex}$ & 0.000 & 0 & 0.000 & 0 & 0.000 & 0 & & & 0.000 & 0 \\
\hline $\operatorname{demog} 1$ & $0.006^{* *}$ & 28 & $0.010 * * *$ & 27 & $0.016 * * *$ & 18 & & & $0.013 * * *$ & 20 \\
\hline $\operatorname{demog} 2$ & $0.011 * * *$ & 52 & $0.014 * * *$ & 37 & $0.012 * * *$ & 13 & & & $-0.002 *$ & -3 \\
\hline $\operatorname{demog} 3$ & -0.001 & -5 & -0.002 & -5 & $-0.016 * *$ & -18 & & & $-0.016 * * *$ & -24 \\
\hline educ & $-0.007 * * *$ & -33 & $-0.014 * * *$ & -37 & $0.054 * * *$ & 61 & & & $0.038 * * *$ & 57 \\
\hline LM & $-0.003 * * *$ & -14 & $0.006^{* * *}$ & 16 & $0.007 * * *$ & 8 & & & $0.016 * * *$ & 24 \\
\hline \multirow[t]{2}{*}{ asini } & $0.015 * * *$ & 70 & $0.023 * * *$ & 61 & $0.015 * * *$ & 17 & & & $0.016 * * *$ & 24 \\
\hline & & 99 & & 99 & & 99 & & & & 98 \\
\hline$P(x=0)$ & 0.773 & & 0.773 & & 0.773 & & & & 0.773 & \\
\hline $\mathrm{P}(\mathrm{x}=1)$ & 0.681 & & 0.312 & & 0.226 & & & & 0.302 & \\
\hline Diff & 0.092 & & 0.461 & & 0.547 & & & & 0.471 & \\
\hline Exp & 0.021 & 3 & 0.037 & 5 & 0.089 & 12 & & & 0.067 & 9 \\
\hline Unexp & 0.071 & 9 & 0.424 & 55 & 0.458 & 59 & & & 0.405 & 52 \\
\hline
\end{tabular}

Source: 2005 SFS, 2007 SCF, 2007 SOEP, 2008 SHIW, 2007 PSELL3 and 2008 EFF Note: Details of variable groupings (demog1, educ, etc) found in Table A.2 
Table 5: Decomposition of portfolio participation decison for 25 to 49 year olds (Financial Assets and Risky Assets).

\begin{tabular}{|c|c|c|c|c|c|c|c|c|c|c|}
\hline & $\begin{array}{c}\text { Canada } \\
\text { (1) }\end{array}$ & $\%$ & $\begin{array}{c}\text { Germany } \\
\text { (2) }\end{array}$ & $\%$ & $\begin{array}{c}\text { Italy } \\
(3)\end{array}$ & $\%$ & $\begin{array}{c}\text { Luxembourg } \\
\text { (4) }\end{array}$ & $\%$ & $\begin{array}{l}\text { Spain } \\
(5)\end{array}$ & $\%$ \\
\hline \multicolumn{11}{|c|}{ Financial Assets } \\
\hline sex & $0.001^{*}$ & 3 & $-0.003 * * *$ & -6 & $0.003 * * *$ & 5 & $-0.002 * * *$ & 21 & $-0.001 * * *$ & -2 \\
\hline demog 1 & $0.011 * * *$ & 37 & $0.011 * * *$ & 24 & $0.016^{* * *}$ & 26 & $0.012 * * *$ & -125 & $0.014 * * *$ & 28 \\
\hline $\operatorname{demog} 2$ & $0.019 * * *$ & 64 & $0.016 * * *$ & 35 & $0.014 * * *$ & 23 & $0.012 * * *$ & -125 & $0.011 * * *$ & 22 \\
\hline $\operatorname{demog} 3$ & $-0.014 * * *$ & -47 & $-0.020 * * *$ & -43 & $-0.036 * * *$ & -58 & $-0.030 * * *$ & 313 & $-0.029 * * *$ & -57 \\
\hline educ & $-0.007 * * *$ & -24 & $-0.004 * * *$ & -9 & $0.068 * * *$ & 110 & $0.025 * * *$ & -261 & $0.041 * * *$ & 81 \\
\hline LM & 0.001 & 3 & $0.008 * * *$ & 17 & $-0.012 * * *$ & -19 & 0.000 & 0 & $0.008 * *$ & 16 \\
\hline asini & $0.021 * * *$ & 71 & $0.039 * * *$ & 84 & $0.020 * * *$ & 32 & $-0.016 * * *$ & 167 & $0.025 * * *$ & 50 \\
\hline \multirow[t]{2}{*}{ asinwf } & $-0.003 * * *$ & -10 & -0.000 & 0 & $-0.011 * * *$ & -18 & $-0.011 * * *$ & 115 & $-0.017 * * *$ & -34 \\
\hline & & 98 & & 102 & & 100 & & 104 & & 103 \\
\hline$P(x=0)$ & 0.920 & & 0.920 & & 0.920 & & 0.920 & & 0.920 & \\
\hline $\mathrm{P}(\mathrm{x}=1)$ & 0.862 & & 0.523 & & 0.797 & & 0.644 & & 0.920 & \\
\hline Diff & 0.058 & & 0.397 & & 0.122 & & 0.276 & & -0.001 & \\
\hline Exp & 0.030 & 3 & 0.046 & 5 & 0.062 & 7 & -0.010 & -1 & 0.051 & 5 \\
\hline Unexp & 0.029 & 3 & 0.351 & 38 & 0.060 & 7 & 0.286 & 31 & -0.051 & -6 \\
\hline \multicolumn{11}{|c|}{ Risky Assets } \\
\hline sex & 0.005 & 6 & na & & 0.004 & 3 & na & & 0.009 & 8 \\
\hline demog 1 & -0.002 & -2 & & & -0.002 & -1 & & & -0.002 & -2 \\
\hline $\operatorname{demog} 2$ & -0.002 & -2 & & & 0.001 & 1 & & & -0.001 & -1 \\
\hline $\operatorname{demog} 3$ & -0.001 & 0 & & & -0.001 & -1 & & & $-0.003 *$ & -3 \\
\hline educ & $-0.002 * * *$ & -2 & & & $0.082 * * *$ & 61 & & & $0.047 * * *$ & 44 \\
\hline LM & 0.000 & 0 & & & $0.004 * * *$ & 3 & & & $0.010 * * *$ & 9 \\
\hline asini & $0.070 * * *$ & 82 & & & $0.049 * * *$ & 36 & & & $0.054 * * *$ & 50 \\
\hline \multirow[t]{2}{*}{ asinwr } & $0.017 * * *$ & 20 & & & $-0.003 * * *$ & -2 & & & $-0.006 * * *$ & -6 \\
\hline & & 101 & & & & 99 & & & & 101 \\
\hline $\mathrm{P}(\mathrm{x}=0)$ & 0.326 & & & & 0.326 & & & & 0.326 & \\
\hline $\mathrm{P}(\mathrm{x}=1)$ & 0.248 & & & & 0.165 & & & & 0.025 & \\
\hline Diff & 0.077 & & & & 0.161 & & & & 0.301 & \\
\hline Exp & 0.086 & 26 & & & 0.135 & 41 & & & 0.107 & 33 \\
\hline Unexp & -0.009 & -3 & & & 0.026 & 8 & & & 0.194 & 60 \\
\hline
\end{tabular}

Source: 2005 SFS, 2007 SCF, 2007 SOEP, 2008 SHIW, 2007 PSELL3 and 2008 EFF Note: Details of variable groupings (demog1, educ, etc) found in Table A.2 
Table 6: Percentage difference in explained and unexplained participation gaps between the US and each country by cohort

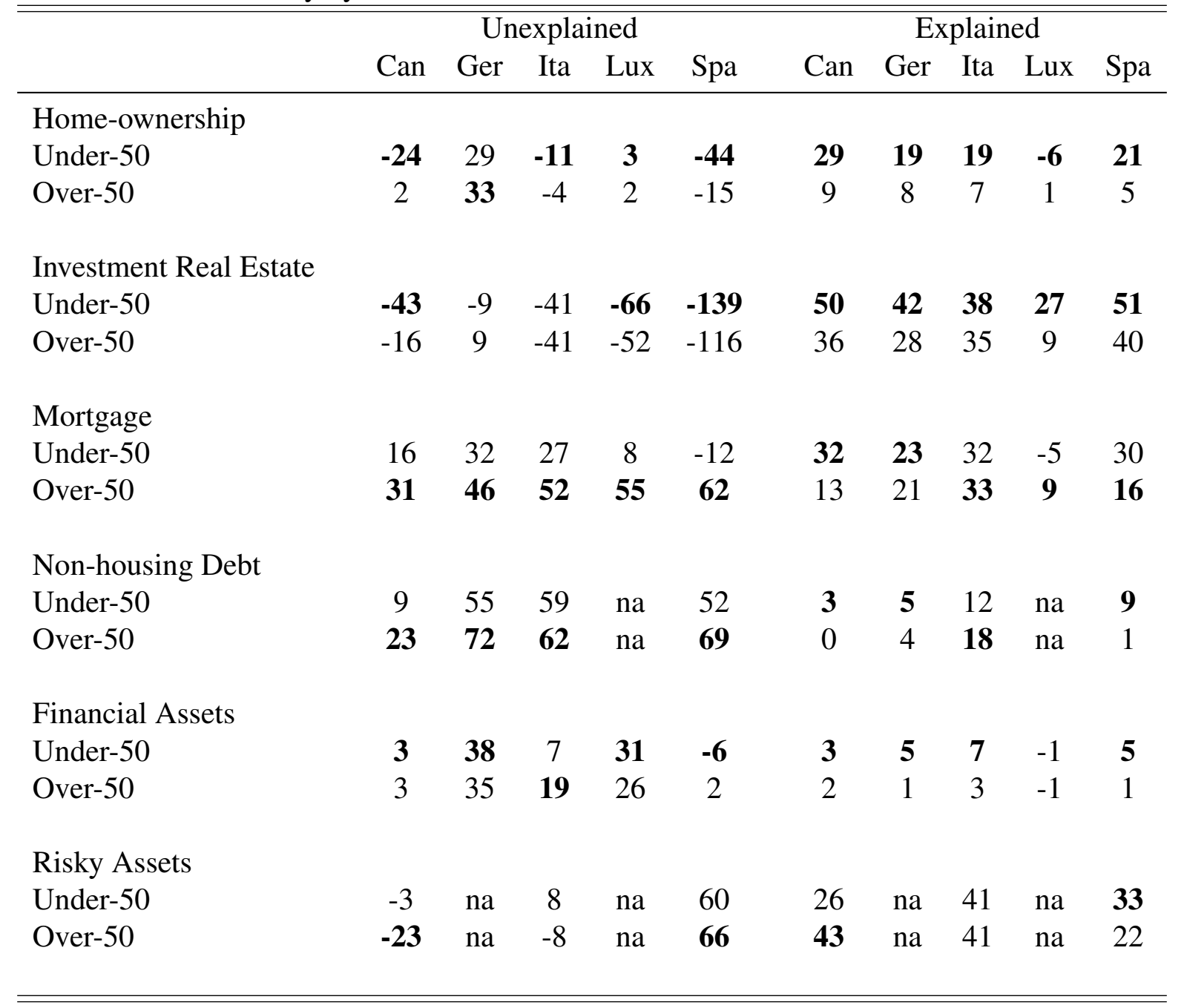

The unexplained gap show the percentage difference in participation that cannot be explained by observable household characteristics and is attributable to country-specific culture, institutions and preferences. The explained gap shows the percentage difference in participation that is attributable to demographics and other observable household characteristics. 
Table 7: Institutional Indices.

\begin{tabular}{|c|c|c|c|}
\hline Index & Description & Scale & Source \\
\hline Financial development & $\begin{array}{l}\text { Measures the beadth, depth and efficiency of financial systems } \\
\text { and capital markets }\end{array}$ & $\begin{array}{l}1-7 \text { with higher values } \\
\text { indicating more development }\end{array}$ & Financial development report 2008 \\
\hline Economic freedom & Measures the level of government interference in the economy & $\begin{array}{l}0-100 \text { with higher values } \\
\text { indicating more freedom }\end{array}$ & 2007 Index of Economic Freedom \\
\hline Bank regulation & $\begin{array}{l}\text { Measures anticompetitive regulations in banking taking into } \\
\text { account regulatory barriers on domestic and foreign entry, restrictions } \\
\text { on banking activities and the extent of government ownership }\end{array}$ & $\begin{array}{l}0-5 \text { with higher values } \\
\text { indicating more regulation }\end{array}$ & Andrews et al, 2011 \\
\hline Marginal Tax Rate & $\begin{array}{l}\text { Net personal marginal tax rate of the principal earner } \\
\text { in a one-earner couple with two children in } 2007\end{array}$ & $\%$ & OECD Stat \\
\hline Mortgage Maturity & Typical mortgage maturity term & years & Andrews et al, 2011 \\
\hline Fixed rate mortgages & $\begin{array}{l}\text { Prevailing type of interest rate. Measured as the proprtion } \\
\text { of fixed rate mortgages. }\end{array}$ & $\%$ & Andrews et al, 2011 \\
\hline Max. LTV ratio & Regulatory limit on mortgage loan to value limits & $\%$ & Andrews et al, 2011 \\
\hline Mathematical literacy & Measures the mathematical skills of 15 year olds & $\begin{array}{l}\text { The average score among OECD } \\
\text { countries is } 500 \text { points and the } \\
\text { standard deviation is } 100 \text { points. }\end{array}$ & PISA 2006 \\
\hline
\end{tabular}

Table 8: Coefficients from a bivariate regression of the unexplained wealth participation gap on institutional indices.

\begin{tabular}{lcccccccc}
\hline \hline & & & & & & & & \\
& PR u-50 & PR o-50 & IR u-50 & IR o-50 & MG u-50 & MG o-50 & NHD u-50 & NHD o-50 \\
\hline Financial Development & -16.88 & -9.88 & -48.34 & -48.89 & 12.70 & $36.73^{*}$ & 40.48 & 42.18 \\
Economic Freedom & -0.74 & -0.35 & -2.17 & -2.46 & 1.37 & 2.06 & $3.45^{* *}$ & 3.51 \\
Bank Regulation & 1.46 & 5.53 & -54.41 & -44.51 & -2.41 & 15.66 & 20.10 & 30.42 \\
Marginal Tax Rate & -0.35 & -0.76 & -1.67 & -2.14 & -0.22 & 0.03 & -0.01 & -0.33 \\
Mortgage Maturity & -1.72 & -1.13 & -4.99 & -5.15 & 1.14 & $3.49 *$ & 3.85 & 3.95 \\
Prop. of fixed rate mortgages & -0.21 & -0.22 & -0.77 & $-0.81^{*}$ & -0.01 & 0.04 & 0.43 & 0.40 \\
Max LTV & 0.67 & 0.65 & 0.53 & 0.55 & 0.86 & 0.37 & 1.58 & 1.83 \\
Math Literacy & -0.09 & -0.30 & -0.25 & -0.64 & 0.28 & 0.06 & 0.36 & 0.16
\end{tabular}

Source: 2005 SFS, 2007 SCF, 2007 SOEP, 2008 SHIW, 2007 PSELL3 and 2008 EFF

Note: The dependent variable is the unexplained gap in wealth participation between the US and the reference country.

PR is Principal Residence, IR is Investment Real Estate, MG is Mortgage and NHD is Non-housing debt.

$\mathrm{u}-50$ refers to households whose head is under 50 years of age while o-50 refers to those whose head is over 50 years of age. 
$\overline{\text { Figure } 1 \text { Participation across the income distribution for } 25 \text { to } 49 \text { population (top) and } 50}$ and over (bottom).
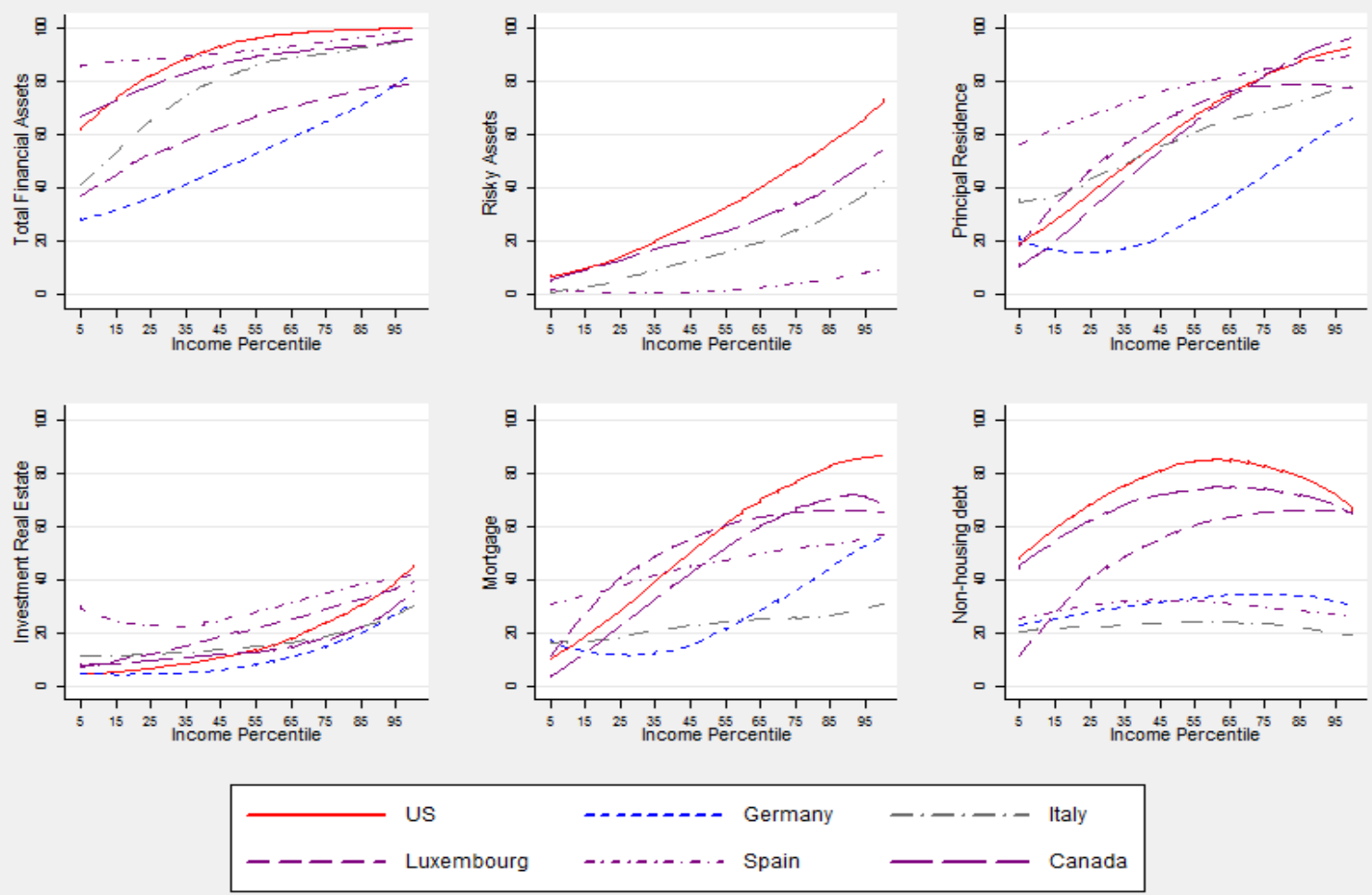

Participation across the income distribution for 50 and over (below)
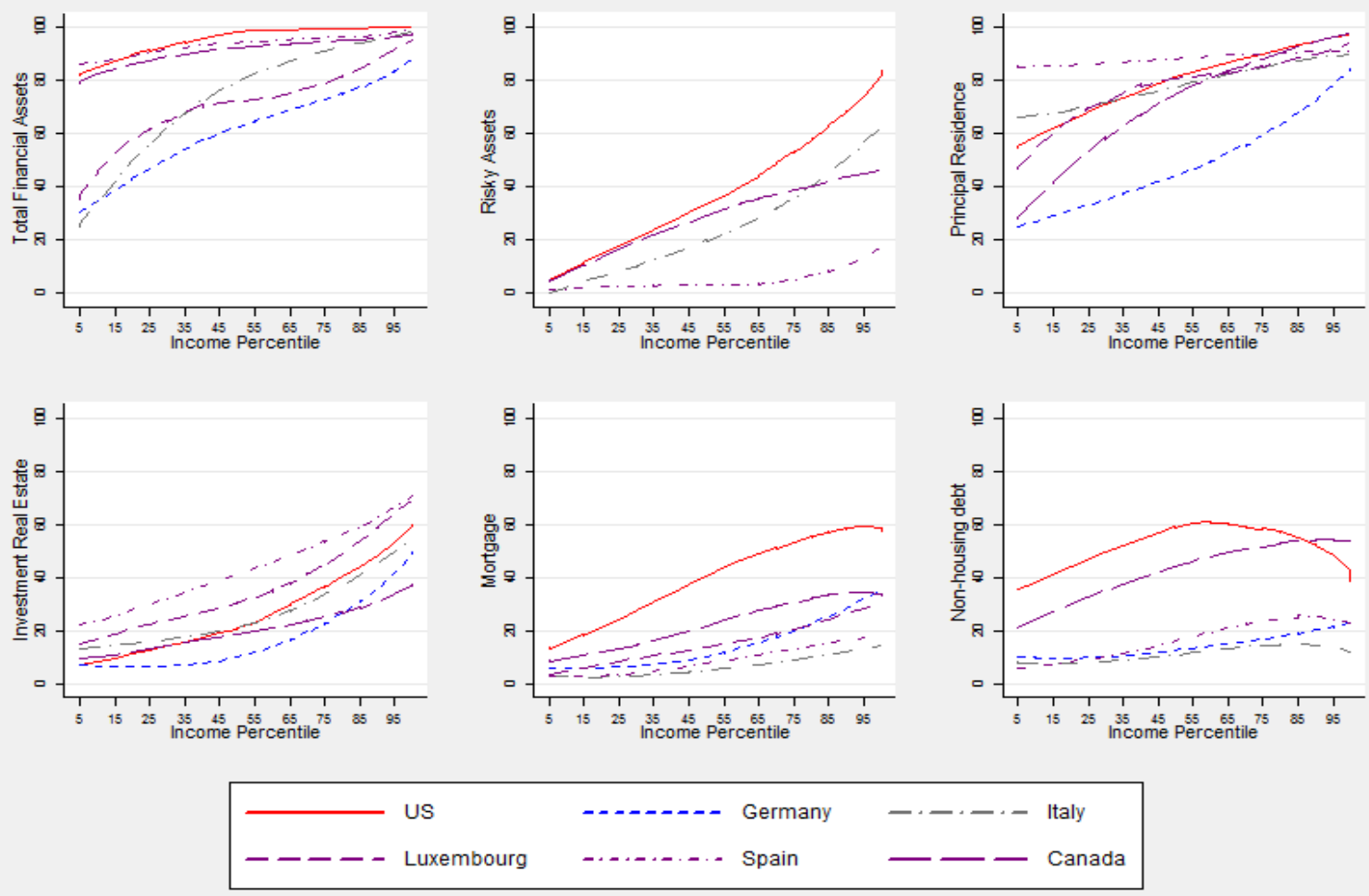

Source: 2005 SFS, 2007 SCF, 2007 SOEP, 2008 SHIW, 2007 PSELL3 and 2008 EFF Note: Weighted statistics. Lowess curve applied for smoothing purposes. 


\section{Appendix}

Table A.1: Overview of wealth portfolio components across the sample surveys.

\begin{tabular}{|c|c|c|c|c|c|c|c|}
\hline \multicolumn{2}{|l|}{ Components } & US & Canada & Germany & Italy & Luxembourg & Spain \\
\hline \multirow[t]{3}{*}{ Financial Assets } & & sum & sum & $\mathrm{X}$ & sum & collected in brackets & sum \\
\hline & Deposit accounts & $\mathrm{X}$ & $\mathrm{X}$ & not included & $\mathrm{X}$ & na & $\mathrm{X}$ \\
\hline & Risky assets & $X$ & $\mathrm{X}$ & na & $\mathrm{X}$ & na & $\mathrm{X}$ \\
\hline \multicolumn{2}{|c|}{ Principle residence: current value of own home } & $\mathrm{X}$ & $\mathrm{X}$ & $\mathrm{X}$ & $\mathrm{X}$ & $\mathrm{X}$ & $\mathrm{X}$ \\
\hline \multicolumn{2}{|c|}{ Investment real estate } & $X$ & $\mathrm{X}$ & $\mathrm{X}$ & $X$ & net of mortgages & $X$ \\
\hline \multicolumn{2}{|c|}{ Business Equity } & $\mathrm{X}$ & $\mathrm{X}$ & $\mathrm{X}$ & $\mathrm{X}$ & $\mathrm{X}$ & $\mathrm{X}$ \\
\hline \multicolumn{2}{|l|}{ Total Debt } & sum & sum & sum & sum & sum & sum \\
\hline \multirow[t]{3}{*}{ Total Mortgage } & & sum & sum & sum & $\mathrm{X}$ & na & sum \\
\hline & Mortgages (main home) & $\mathrm{X}$ & $\mathrm{X}$ & $\mathrm{X}$ & na & $\mathrm{X}$ & $\mathrm{X}$ \\
\hline & Other mortgages & $\mathrm{X}$ & $\mathrm{X}$ & $\mathrm{X}$ & na & na & $X$ \\
\hline Non-housing debt & & $\mathrm{X}$ & $\mathrm{X}$ & $\mathrm{X}$ & $\mathrm{X}$ & na & $\mathrm{X}$ \\
\hline
\end{tabular}

Source: 2005 SFS, 2007 SCF, 2007 SOEP, 2008 SHIW, 2007 PSELL3 and 2008 EFF

Table A.2: Glossary of sets of characteristics and variables for the two cohorts

\begin{tabular}{ll}
\hline \hline Set & Variables included (25 to 49 year olds) \\
\hline demog1 & single $(0 / 1)$, single parents $(0 / 1)$, couples no kids $(0 / 1)$, couples with kids $(0 / 1)$ aged under 30 years old \\
demog2 & single $(0 / 1)$, single parents $(0 / 1)$, couples no kids $(0 / 1)$, couples with kids $(0 / 1)$ aged 30-39 years old \\
demog3 & single $(0 / 1)$, single parents $(0 / 1)$, couples no kids $(0 / 1)$, couples with kids $(0 / 1)$ aged $40-49$ years old \\
educ & indicator variable for low, medium and high education \\
LM & employed $(0 / 1)$, self-employed $(0 / 1)$, retired $(0 / 1)$ \\
asini & household disposable income \\
asiniw & other wealth \\
\hline \hline
\end{tabular}

\begin{tabular}{ll}
\hline \hline Set & Variables included $(50$ and over $)$ \\
\hline demog1 & single $(0 / 1)$, single parents $(0 / 1)$, couples no kids $(0 / 1)$, couples with kids $(0 / 1)$ aged $50-59$ years old \\
demog2 & single $(0 / 1)$, single parents $(0 / 1)$, couples no kids $(0 / 1)$, couples with kids $(0 / 1)$ aged $60-69$ years old \\
demog3 & single $(0 / 1)$, single parents $(0 / 1)$, couples no kids $(0 / 1)$, couples with kids $(0 / 1)$ aged 70 and over \\
educ & indicator variable for low, medium and high education \\
LM & employed $(0 / 1)$, self-employed $(0 / 1)$, retired $(0 / 1)$ \\
asini & household disposable income \\
asiniw & other wealth \\
\hline \hline
\end{tabular}


Table A.3: Marginal effects for asset participation for those 25 to 49 years old (principal residence, investment real estate and mortgage).

\begin{tabular}{|c|c|c|c|c|c|c|c|c|c|c|c|c|}
\hline & (1) & (2) & (3) & (4) & $(5)$ & (6) & $(7)$ & (8) & $(9)$ & (10) & $(11)$ & (12) \\
\hline Principal Residence (PR) & US & se & Canada & $\mathrm{se}$ & Germany & $\mathrm{se}$ & Italy & se & Luxembourg & se & Spain & $\mathrm{se}$ \\
\hline male $(0 / 1)$ & $0.036^{*}$ & $(0.021)$ & 0.032 & $(0.036)$ & -0.012 & $(0.010)$ & 0.008 & $(0.034)$ & $-0.055 * * *$ & $(0.017)$ & $0.067 * *$ & $(0.032)$ \\
\hline SP lt 30 & $-0.003 * * *$ & $(0.001)$ & $-0.004 * * *$ & $(0.002)$ & $-0.005 * * *$ & $(0.001)$ & 0.001 & $(0.002)$ & $-0.003 * *$ & $(0.001)$ & 0.000 & $(0.002)$ \\
\hline CP lt 30 & -0.000 & $(0.000)$ & 0.000 & $(0.001)$ & $0.002 * * *$ & $(0.000)$ & 0.001 & $(0.001)$ & -0.001 & $(0.001)$ & 0.002 & $(0.001)$ \\
\hline CPK lt 30 & $0.002 * * *$ & $(0.000)$ & 0.001 & $(0.001)$ & $0.004 * * *$ & $(0.000)$ & 0.001 & $(0.001)$ & -0.001 & $(0.001)$ & $0.002 *$ & $(0.001)$ \\
\hline S 30-39 yrs old & $0.001 * * *$ & $(0.000)$ & 0.000 & $(0.001)$ & $0.002 * * *$ & $(0.000)$ & 0.001 & $(0.001)$ & $0.001 *$ & $(0.000)$ & 0.001 & $(0.001)$ \\
\hline SP 30-39 yrs old & $0.002 * * *$ & $(0.000)$ & 0.001 & $(0.001)$ & $0.002 * * *$ & $(0.000)$ & $0.002 *$ & $(0.001)$ & 0.001 & $(0.001)$ & $0.002 * *$ & $(0.001)$ \\
\hline CP 30-39 yrs old & $0.002 * * *$ & $(0.000)$ & $0.002 * * *$ & $(0.001)$ & $0.003 * * *$ & $(0.000)$ & $0.002 *$ & $(0.001)$ & 0.000 & $(0.001)$ & 0.001 & $(0.001)$ \\
\hline CPK $30-39$ yrs old & $0.004 * * *$ & $(0.000)$ & $0.003 * * *$ & $(0.001)$ & $0.005 * * *$ & $(0.000)$ & $0.003 * * *$ & $(0.001)$ & $0.002 * * *$ & $(0.001)$ & $0.003 * * *$ & $(0.001)$ \\
\hline S 40-49 yrs old & $0.003 * * *$ & $(0.000)$ & $0.002 * *$ & $(0.001)$ & $0.003 * * *$ & $(0.000)$ & $0.002 * * *$ & $(0.001)$ & $0.001 * * *$ & $(0.000)$ & $0.002 * * *$ & $(0.001)$ \\
\hline SP 40-49 yrs old & $0.002 * * *$ & $(0.000)$ & $0.002 * *$ & $(0.001)$ & $0.003 * * *$ & $(0.000)$ & $0.002 *$ & $(0.001)$ & $0.002 * * *$ & $(0.001)$ & $0.003^{* * *} *$ & $(0.001)$ \\
\hline CP 40-49 yrs old & $0.004 * * *$ & $(0.000)$ & $0.004 * * *$ & $(0.001)$ & $0.006^{* * *}$ & $(0.000)$ & $0.002 * * *$ & $(0.001)$ & $0.003 * * *$ & $(0.001)$ & $0.003 * * *$ & $(0.001)$ \\
\hline CPK $40-49$ yrs old & $0.004 * * *$ & $(0.000)$ & $0.005 * * *$ & $(0.001)$ & $0.006 * * *$ & $(0.000)$ & $0.004 * * *$ & $(0.001)$ & $0.003^{* * *}$ & $(0.001)$ & $0.003^{* * *} *$ & $(0.001)$ \\
\hline low education & $-0.194 * * *$ & $(0.020)$ & -0.080 & $(0.055)$ & $-0.102 * * *$ & $(0.015)$ & $-0.189 * * *$ & $(0.034)$ & $-0.131 * * *$ & $(0.022)$ & -0.015 & $(0.034)$ \\
\hline high education & -0.018 & $(0.018)$ & -0.057 & $(0.035)$ & 0.009 & $(0.010)$ & 0.022 & $(0.049)$ & $-0.182 * * *$ & $(0.028)$ & 0.009 & $(0.038)$ \\
\hline employed & $0.112 * * *$ & $(0.024)$ & 0.062 & $(0.084)$ & $0.148 * * *$ & $(0.012)$ & -0.065 & $(0.048)$ & $0.047 *$ & $(0.027)$ & 0.017 & $(0.032)$ \\
\hline self-employed & $0.148 * * *$ & $(0.032)$ & $0.216^{* *}$ & $(0.095)$ & $0.198 * * *$ & $(0.020)$ & 0.035 & $(0.061)$ & $0.084 * *$ & $(0.037)$ & 0.050 & $(0.061)$ \\
\hline income & $0.219 * * *$ & $(0.025)$ & $0.280 * * *$ & $(0.083)$ & $-0.009 * * *$ & $(0.001)$ & 0.006 & $(0.012)$ & $0.169 * * *$ & $(0.062)$ & $0.022 * * *$ & $(0.008)$ \\
\hline wealth (non-PR) & $0.004 * * *$ & $(0.001)$ & $0.004 * *$ & $(0.002)$ & $0.007 * * *$ & $(0.001)$ & $0.010 * * *$ & $(0.002)$ & $0.004 * *$ & $(0.002)$ & $0.007 * * *$ & $(0.002)$ \\
\hline \multirow[t]{2}{*}{ Observations } & 9,240 & & 2,438 & & 23,615 & & 2,539 & & 11,036 & & 1,809 & \\
\hline & (1) & (2) & (3) & (4) & (5) & (6) & (7) & (8) & (9) & (10) & (11) & (12) \\
\hline Investment real estate (IR) & US & se & Canada & se & Germany & se & Italy & se & Luxembourg & se & Spain & se \\
\hline male $(0 / 1)$ & $0.130 * * *$ & $(0.017)$ & -0.020 & $(0.018)$ & 0.002 & $(0.004)$ & 0.002 & $(0.021)$ & $0.019 * * *$ & $(0.006)$ & -0.028 & $(0.033)$ \\
\hline SP lt 30 & & & -0.001 & $(0.001)$ & 0.000 & $(0.000)$ & $0.002 * *$ & $(0.001)$ & $0.001 * * *$ & $(0.000)$ & & \\
\hline CP lt 30 & 0.001 & $(0.000)$ & -0.000 & $(0.001)$ & $0.001 * * *$ & $(0.000)$ & $-0.003 * *$ & $(0.001)$ & $0.001^{* * * *}$ & $(0.000)$ & -0.002 & $(0.002)$ \\
\hline CPK 1t 30 & 0.000 & $(0.000)$ & -0.000 & $(0.001)$ & $0.000 * *$ & $(0.000)$ & -0.000 & $(0.001)$ & $0.000^{*}$ & $(0.000)$ & -0.001 & $(0.002)$ \\
\hline S $30-39$ yrs old & $0.001 * *$ & $(0.000)$ & 0.000 & $(0.000)$ & 0.000 & $(0.000)$ & -0.000 & $(0.001)$ & $0.000^{* *}$ & $(0.000)$ & 0.000 & $(0.001)$ \\
\hline SP $30-39$ yrs old & $0.001 * * *$ & $(0.000)$ & 0.000 & $(0.001)$ & $-0.001 * * *$ & $(0.000)$ & -0.000 & $(0.001)$ & 0.000 & $(0.000)$ & -0.000 & $(0.001)$ \\
\hline CP $30-39$ yrs old & 0.001 & $(0.000)$ & 0.000 & $(0.000)$ & $0.001 * * *$ & $(0.000)$ & 0.000 & $(0.001)$ & 0.000 & $(0.000)$ & -0.001 & $(0.001)$ \\
\hline CPK $30-39$ yrs old & $0.001 * * *$ & $(0.000)$ & 0.000 & $(0.000)$ & $0.001 * * *$ & $(0.000)$ & 0.000 & $(0.000)$ & $0.000^{* *}$ & $(0.000)$ & 0.000 & $(0.001)$ \\
\hline S $40-49$ yrs old & $0.001 * *$ & $(0.000)$ & -0.000 & $(0.000)$ & $0.000^{* *}$ & $(0.000)$ & 0.001 & $(0.001)$ & 0.000 & $(0.000)$ & 0.001 & $(0.001)$ \\
\hline SP $40-49$ yrs old & $0.002 * * *$ & $(0.000)$ & 0.000 & $(0.001)$ & $0.000 * * *$ & $(0.000)$ & 0.000 & $(0.001)$ & 0.000 & $(0.000)$ & -0.001 & $(0.001)$ \\
\hline CP $40-49$ yrs old & $0.001 * *$ & $(0.000)$ & 0.001 & $(0.000)$ & $0.001 * * *$ & $(0.000)$ & $0.001 *$ & $(0.001)$ & -0.000 & $(0.000)$ & 0.001 & $(0.001)$ \\
\hline CPK 40-49 yrs ol & $0.001 * * *$ & $(0.000)$ & 0.001 & $(0.000)$ & $0.001 * * *$ & $(0.000)$ & 0.001 & $(0.000)$ & 0.000 & $(0.000)$ & 0.001 & $(0.001)$ \\
\hline low education & $-0.045^{* * *}$ & $(0.014)$ & 0.011 & $(0.029)$ & -0.004 & $(0.007)$ & $-0.041^{* *}$ & $(0.020)$ & $0.037 * * *$ & $(0.008)$ & -0.053 & $(0.039)$ \\
\hline high education & 0.013 & $(0.009)$ & 0.021 & $(0.018)$ & $0.051 * * *$ & $(0.004)$ & 0.031 & $(0.026)$ & $0.026^{* * *}$ & $(0.007)$ & 0.059 & $(0.041)$ \\
\hline employed & -0.006 & $(0.016)$ & 0.021 & $(0.041)$ & 0.004 & $(0.006)$ & -0.033 & $(0.028)$ & $-0.016^{*}$ & $(0.009)$ & -0.039 & $(0.039)$ \\
\hline self-employed & $0.077 * * *$ & $(0.018)$ & $0.080 *$ & $(0.045)$ & $0.032 * * *$ & $(0.008)$ & 0.042 & $(0.033)$ & 0.017 & $(0.011)$ & $0.221 * * *$ & $(0.066)$ \\
\hline income & $0.069 * * *$ & $(0.009)$ & 0.012 & $(0.026)$ & 0.000 & $(0.001)$ & 0.005 & $(0.008)$ & 0.014 & $(0.009)$ & 0.011 & $(0.011)$ \\
\hline wealth (non-IR) & $0.001 *$ & $(0.001)$ & $0.006 * * *$ & $(0.001)$ & $0.005^{* * * *}$ & $(0.000)$ & $0.009 * * *$ & $(0.002)$ & $0.041 * * *$ & $(0.002)$ & $0.010 * * *$ & (0.004) \\
\hline \multirow[t]{2}{*}{ Observations } & 9,060 & & 2,438 & & 23,615 & & 2,539 & & 11,036 & & 1,804 & \\
\hline & (1) & (2) & (3) & (4) & (5) & (6) & (7) & (8) & (9) & (10) & (11) & (12) \\
\hline Mortgage $\mathrm{n}(\mathrm{MG})$ & US & se & Canada & se & Germany & $\mathrm{se}$ & Italy & $\mathrm{se}$ & Luxembourg & se & Spain & $\mathrm{se}$ \\
\hline male $(0 / 1)$ & -0.028 & $(0.023)$ & 0.036 & $(0.034)$ & -0.010 & $(0.008)$ & 0.005 & $(0.029)$ & $-0.041^{* *}$ & $(0.018)$ & 0.038 & $(0.038)$ \\
\hline SP lt 30 & $-0.003 * * *$ & $(0.001)$ & -0.004 & $(0.002)$ & & & & & $-0.004 * * *$ & $(0.001)$ & 0.003 & $(0.003)$ \\
\hline CP lt 30 & 0.000 & $(0.001)$ & $0.002 * * *$ & $(0.001)$ & $0.002 * * *$ & $(0.000)$ & 0.000 & $(0.001)$ & -0.001 & $(0.001)$ & $0.005 * * *$ & $(0.002)$ \\
\hline CPK lt 30 & $0.002 * * *$ & $(0.000)$ & $0.003 * * *$ & $(0.001)$ & $0.004 * * *$ & $(0.000)$ & 0.001 & $(0.001)$ & -0.000 & $(0.001)$ & $0.005^{* * * *}$ & $(0.001)$ \\
\hline S 30-39 yrs old & $0.001 * * *$ & $(0.000)$ & $0.001 *$ & $(0.001)$ & $0.002 * * *$ & $(0.000)$ & 0.000 & $(0.001)$ & 0.001 & $(0.000)$ & 0.001 & $(0.001)$ \\
\hline SP $30-39$ yrs old & $0.002 * * *$ & $(0.000)$ & $0.002 *$ & $(0.001)$ & $0.002 * * *$ & $(0.000)$ & 0.000 & $(0.001)$ & -0.000 & $(0.001)$ & $0.003 * *$ & $(0.001)$ \\
\hline CP $30-39$ yrs old & $0.002 * * *$ & $(0.000)$ & $0.004 * * *$ & $(0.001)$ & $0.003 * * *$ & $(0.000)$ & $0.002 *$ & $(0.001)$ & 0.001 & $(0.001)$ & $0.003 * *$ & $(0.001)$ \\
\hline CPK $30-39$ yrs old & $0.004 * * *$ & $(0.000)$ & $0.005^{* * *}$ & $(0.001)$ & $0.005^{* * * *}$ & $(0.000)$ & $0.001 *$ & $(0.001)$ & $0.002 * * *$ & $(0.001)$ & $0.005^{* * *}$ & $(0.001)$ \\
\hline S $40-49$ yrs old & $0.003 * * *$ & $(0.000)$ & $0.001 * *$ & $(0.001)$ & $0.002 * * *$ & $(0.000)$ & -0.000 & $(0.001)$ & 0.000 & $(0.001)$ & 0.000 & $(0.001)$ \\
\hline SP $40-49$ yrs old & $0.002 * * *$ & $(0.000)$ & $0.003 * * *$ & $(0.001)$ & $0.002 * * *$ & $(0.000)$ & 0.000 & $(0.001)$ & -0.000 & $(0.001)$ & $0.003 * *$ & $(0.001)$ \\
\hline CP 40-49 yrs old & $0.004 * * *$ & $(0.000)$ & $0.003 * * *$ & $(0.001)$ & $0.004 * * *$ & $(0.000)$ & 0.001 & $(0.001)$ & $0.002 * * *$ & $(0.001)$ & $0.003 * *$ & $(0.001)$ \\
\hline CPK 40-49 yrs ol & $0.004 * * *$ & $(0.000)$ & $0.004 * * *$ & $(0.001)$ & $0.005^{* * *}$ & $(0.000)$ & 0.001 & $(0.001)$ & $0.002 * * *$ & $(0.001)$ & $0.003 * *$ & $(0.001)$ \\
\hline low education & $-0.257 * * *$ & $(0.023)$ & $-0.189 * * *$ & $(0.055)$ & $-0.068 * * *$ & $(0.013)$ & $-0.088 * * *$ & $(0.027)$ & $-0.098 * * *$ & $(0.025)$ & $-0.083 * *$ & $(0.040)$ \\
\hline high education & 0.014 & $(0.018)$ & -0.032 & $(0.033)$ & $0.029 * * *$ & $(0.009)$ & 0.035 & $(0.037)$ & $-0.144 * * *$ & $(0.028)$ & 0.069 & $(0.049)$ \\
\hline employed & $0.142 * * *$ & $(0.026)$ & $0.226 * * *$ & $(0.080)$ & $0.122 * * *$ & $(0.010)$ & 0.057 & $(0.038)$ & $0.172 * * *$ & $(0.028)$ & $0.091 * *$ & $(0.042)$ \\
\hline self-employed & $0.178 * * *$ & $(0.034)$ & $0.192 * *$ & $(0.091)$ & $0.201 * * *$ & $(0.016)$ & $0.130 * * *$ & $(0.045)$ & $0.168 * * *$ & $(0.041)$ & 0.026 & $(0.068)$ \\
\hline income & $0.281 * * *$ & $(0.026)$ & $0.146 * *$ & $(0.063)$ & $-0.007 * * *$ & $(0.001)$ & -0.006 & $(0.008)$ & $0.127 * *$ & $(0.053)$ & 0.006 & $(0.013)$ \\
\hline Observations & 9,240 & & 2,438 & & 23,435 & & 2,531 & & 11,036 & & 1,809 & \\
\hline
\end{tabular}

Standard errors in parentheses; $* * * \mathrm{p}<0.01, * * \mathrm{p}<0.05, * \mathrm{p}<0.1$

Note: S- singles; SP - single parents; CP -couples without kids; CPK - couples with kids. 
Table A.4: Marginal effects for asset participation for those 25 to 49 year olds (financial assets, non-housing debt and risky assets).

\begin{tabular}{|c|c|c|c|c|c|c|c|c|c|c|c|c|}
\hline & (1) & (2) & (3) & (4) & (5) & (6) & (7) & (8) & (9) & (10) & $(11)$ & (12) \\
\hline Financial Assets (FA) & US & se & Canada & se & Germany & se & Italy & se & Luxembourg & se & Spain & se \\
\hline male $(0 / 1)$ & $-0.013^{* * *}$ & $(0.004)$ & -0.017 & $(0.018)$ & $-0.050 * * *$ & $(0.011)$ & -0.042 & $(0.026)$ & -0.025 & $(0.018)$ & 0.003 & $(0.010)$ \\
\hline SP lt 30 & $-0.000 * * *$ & $(0.000)$ & -0.000 & $(0.001)$ & $-0.006 * * *$ & $(0.001)$ & -0.001 & $(0.001)$ & $-0.004 * * *$ & $(0.001)$ & $-0.005 * * *$ & $(0.001)$ \\
\hline CP lt 30 & $0.000 * *$ & $(0.000)$ & 0.001 & $(0.000)$ & $0.001 * * *$ & $(0.000)$ & 0.001 & $(0.001)$ & -0.001 & $(0.001)$ & & \\
\hline CPK 1t 30 & $0.000 * *$ & $(0.000)$ & 0.000 & $(0.000)$ & $0.001 * * *$ & $(0.000)$ & 0.001 & $(0.001)$ & $-0.002 * * *$ & $(0.001)$ & $-0.005 * * *$ & $(0.001)$ \\
\hline S 30-39 yrs old & -0.000 & $(0.000)$ & -0.000 & $(0.000)$ & $-0.000 * *$ & $(0.000)$ & 0.000 & $(0.001)$ & 0.000 & $(0.000)$ & $-0.005 * * *$ & $(0.001)$ \\
\hline SP $30-39$ yrs old & $-0.000 * *$ & $(0.000)$ & -0.000 & $(0.000)$ & $-0.002 * * *$ & $(0.000)$ & -0.000 & $(0.001)$ & -0.000 & $(0.001)$ & $-0.005 * * *$ & $(0.001)$ \\
\hline CP 30-39 yrs old & $0.000^{* *}$ & $(0.000)$ & -0.000 & $(0.000)$ & $0.002 * * *$ & $(0.000)$ & 0.001 & $(0.001)$ & -0.001 & $(0.001)$ & $-0.005 * * *$ & $(0.001)$ \\
\hline CPK 30-39 yrs old & $0.000 * * *$ & $(0.000)$ & 0.000 & $(0.000)$ & $0.001 * * *$ & $(0.000)$ & 0.000 & $(0.001)$ & $-0.001 * *$ & $(0.001)$ & $-0.005 * * *$ & $(0.001)$ \\
\hline S 40-49 yrs old & 0.000 & $(0.000)$ & $-0.001 * * *$ & $(0.000)$ & -0.000 & $(0.000)$ & 0.001 & $(0.001)$ & -0.001 & $(0.000)$ & $-0.005 * * *$ & $(0.001)$ \\
\hline SP $40-49$ yrs old & -0.000 & $(0.000)$ & 0.000 & $(0.000)$ & $-0.002 * * *$ & $(0.000)$ & -0.000 & $(0.001)$ & $-0.002 * * *$ & $(0.001)$ & $-0.005 * * *$ & $(0.001)$ \\
\hline CP 40-49 yrs old & $0.000 * * *$ & $(0.000)$ & -0.000 & $(0.000)$ & -0.000 & $(0.000)$ & 0.000 & $(0.001)$ & $-0.002 * * *$ & $(0.001)$ & $-0.005 * * *$ & $(0.001)$ \\
\hline CPK 40-49 yrs ol & $0.000 * *$ & $(0.000)$ & 0.000 & $(0.000)$ & 0.000 & $(0.000)$ & 0.000 & $(0.001)$ & -0.001 & $(0.001)$ & $-0.005 * * *$ & $(0.001)$ \\
\hline low education & $-0.037 * * *$ & $(0.005)$ & $-0.067 * * *$ & $(0.022)$ & $-0.195 * * *$ & $(0.017)$ & $-0.110 * * *$ & $(0.024)$ & $-0.198 * * *$ & $(0.022)$ & $-0.040 * * *$ & $(0.010)$ \\
\hline high education & $0.055 * * *$ & $(0.005)$ & $0.053 * *$ & $(0.021)$ & $0.203 * * *$ & $(0.013)$ & 0.031 & $(0.050)$ & 0.034 & $(0.027)$ & 0.010 & $(0.018)$ \\
\hline employed & $0.010 * * *$ & $(0.003)$ & $0.095 * * *$ & $(0.023)$ & $0.145^{* * *}$ & $(0.013)$ & $0.064 * *$ & $(0.032)$ & $0.113 * * *$ & $(0.028)$ & 0.009 & $(0.008)$ \\
\hline self-employed & $0.053 * * *$ & $(0.011)$ & $0.126^{* * *}$ & $(0.039)$ & $-0.036^{*}$ & $(0.022)$ & $0.134 * * *$ & $(0.048)$ & $0.097 * *$ & $(0.044)$ & -0.010 & $(0.020)$ \\
\hline income & $0.011 * * *$ & $(0.002)$ & $0.014 *$ & $(0.007)$ & $0.007 * * *$ & $(0.002)$ & 0.044 & $(0.031)$ & $0.096^{*}$ & $(0.049)$ & 0.003 & $(0.002)$ \\
\hline wealth (non-FA) & $0.000 * * *$ & $(0.000)$ & $0.002^{* *}$ & $(0.001)$ & $0.016^{* * *}$ & $(0.001)$ & $0.005^{* * *}$ & $(0.001)$ & $0.011 * * *$ & $(0.002)$ & $0.002 * * *$ & $(0.001)$ \\
\hline Observations & 9,240 & & 2,438 & & 23,615 & & 2,539 & & 11,036 & & 1,790 & \\
\hline Non-housing debt (NHD) & US & $\mathrm{se}$ & Canada & se & Germany & se & Italy & se & Luxembourg & se & Spain & se \\
\hline male $(0 / 1)$ & 0.001 & $(0.016)$ & -0.034 & $(0.029)$ & $0.024 * * *$ & $(0.009)$ & $-0.051^{*}$ & $(0.027)$ & & & -0.013 & $(0.034)$ \\
\hline SP lt 30 & $-0.002 * * *$ & $(0.000)$ & 0.002 & $(0.001)$ & $0.001 * *$ & $(0.000)$ & & & & & 0.001 & $(0.002)$ \\
\hline CP lt 30 & -0.000 & $(0.000)$ & $0.002 * * *$ & $(0.001)$ & $0.002 * * *$ & $(0.000)$ & $0.002 *$ & $(0.001)$ & & & -0.000 & $(0.002)$ \\
\hline CPK lt 30 & 0.000 & $(0.000)$ & 0.000 & $(0.001)$ & $0.003 * * *$ & $(0.000)$ & $0.002 * *$ & $(0.001)$ & & & 0.000 & $(0.001)$ \\
\hline S 30-39 yrs old & $-0.001 * * *$ & $(0.000)$ & -0.000 & $(0.001)$ & $0.000^{* *}$ & $(0.000)$ & -0.000 & $(0.001)$ & & & $-0.002 *$ & $(0.001)$ \\
\hline SP $30-39$ yrs old & $-0.001^{*}$ & $(0.000)$ & $0.002 * * *$ & $(0.001)$ & $0.002 * * *$ & $(0.000)$ & 0.000 & $(0.001)$ & & & 0.001 & $(0.001)$ \\
\hline CP $30-39$ yrs old & $-0.001 * *$ & $(0.000)$ & 0.000 & $(0.001)$ & $0.002 * * *$ & $(0.000)$ & -0.000 & $(0.001)$ & & & 0.000 & $(0.001)$ \\
\hline CPK 30-39 yrs old & 0.000 & $(0.000)$ & 0.000 & $(0.001)$ & $0.002 * * *$ & $(0.000)$ & 0.001 & $(0.001)$ & & & 0.000 & $(0.001)$ \\
\hline S 40-49 yrs old & $-0.002 * * *$ & $(0.000)$ & -0.001 & $(0.001)$ & $0.001 * * *$ & $(0.000)$ & 0.000 & $(0.001)$ & & & -0.001 & $(0.001)$ \\
\hline SP $40-49$ yrs old & -0.000 & $(0.000)$ & 0.000 & $(0.001)$ & $0.002 * * *$ & $(0.000)$ & 0.001 & $(0.001)$ & & & -0.001 & $(0.001)$ \\
\hline CP 40-49 yrs old & $-0.001 * *$ & $(0.000)$ & 0.000 & $(0.001)$ & $0.002 * * *$ & $(0.000)$ & 0.001 & $(0.001)$ & & & -0.001 & $(0.001)$ \\
\hline CPK 40-49 yrs ol & -0.000 & $(0.000)$ & -0.000 & $(0.001)$ & $0.002 * * *$ & $(0.000)$ & 0.001 & $(0.001)$ & & & 0.000 & $(0.001)$ \\
\hline low education & $-0.164 * * *$ & $(0.013)$ & -0.014 & $(0.047)$ & -0.011 & $(0.014)$ & 0.021 & $(0.024)$ & & & 0.032 & $(0.034)$ \\
\hline high education & $-0.053 * * *$ & $(0.011)$ & $-0.084 * * *$ & $(0.029)$ & $-0.125 * * *$ & $(0.011)$ & $-0.102^{* * *}$ & $(0.039)$ & & & -0.006 & $(0.044)$ \\
\hline employed & $0.101 * * *$ & $(0.015)$ & $0.184 * * *$ & $(0.054)$ & $-0.021 *$ & $(0.011)$ & $0.081 * *$ & $(0.037)$ & & & -0.016 & $(0.038)$ \\
\hline self-employed & 0.030 & $(0.019)$ & $0.177 * * *$ & $(0.065)$ & 0.014 & (0.019) & -0.001 & $(0.045)$ & & & -0.003 & $(0.061)$ \\
\hline income & $0.019 * * *$ & $(0.005)$ & 0.042 & $(0.028)$ & $0.013 * * *$ & $(0.001)$ & 0.001 & $(0.008)$ & & & -0.002 & $(0.010)$ \\
\hline Observations & 9,240 & & 2,438 & & 23,615 & & 2,531 & & & & 1,809 & \\
\hline Risky Assets (RA) & US & se & Canada & se & Germany & se & Italy & se & Luxembourg & se & Spain & se \\
\hline male $(0 / 1)$ & 0.032 & $(0.020)$ & $-0.037 *$ & $(0.022)$ & & & 0.020 & $(0.015)$ & & & 0.002 & $(0.001)$ \\
\hline SP lt 30 & -0.001 & $(0.001)$ & -0.001 & $(0.001)$ & & & & & & & & \\
\hline CP lt 30 & $-0.001 * * *$ & $(0.000)$ & 0.000 & $(0.001)$ & & & -0.001 & $(0.001)$ & & & & \\
\hline CPK 1t 30 & $-0.001 *$ & $(0.000)$ & 0.001 & $(0.001)$ & & & & & & & & \\
\hline S 30-39 yrs old & $-0.001 * * *$ & $(0.000)$ & 0.000 & $(0.001)$ & & & -0.000 & $(0.000)$ & & & 0.000 & $(0.000)$ \\
\hline SP $30-39$ yrs old & $-0.002 * * *$ & $(0.000)$ & 0.000 & $(0.001)$ & & & 0.000 & $(0.001)$ & & & 0.000 & $(0.000)$ \\
\hline CP $30-39$ yrs old & $-0.002 * * *$ & $(0.000)$ & -0.001 & $(0.001)$ & & & -0.000 & $(0.000)$ & & & -0.000 & $(0.000)$ \\
\hline CPK 30-39 yrs old & -0.000 & $(0.000)$ & -0.000 & $(0.000)$ & & & $-0.001 *$ & $(0.000)$ & & & 0.000 & $(0.000)$ \\
\hline S 40-49 yrs old & -0.001 & $(0.000)$ & 0.000 & $(0.001)$ & & & -0.000 & $(0.000)$ & & & 0.000 & $(0.000)$ \\
\hline SP $40-49$ yrs old & $-0.001 * * *$ & $(0.000)$ & 0.000 & $(0.001)$ & & & $-0.001 * *$ & $(0.001)$ & & & 0.000 & $(0.000)$ \\
\hline CP 40-49 yrs old & $-0.001 * * *$ & $(0.000)$ & 0.000 & $(0.000)$ & & & -0.001 & $(0.000)$ & & & 0.000 & $(0.000)$ \\
\hline CPK 40-49 yrs ol & -0.001 & $(0.000)$ & -0.000 & $(0.000)$ & & & -0.001 & $(0.000)$ & & & 0.000 & $(0.000)$ \\
\hline low education & $-0.240 * * *$ & $(0.027)$ & $-0.085^{* *}$ & $(0.041)$ & & & $-0.068 * * *$ & $(0.018)$ & & & -0.002 & $(0.002)$ \\
\hline high education & $0.156 * * *$ & $(0.016)$ & 0.032 & $(0.022)$ & & & -0.012 & $(0.017)$ & & & 0.001 & $(0.001)$ \\
\hline employed & $0.110 * * *$ & $(0.029)$ & 0.051 & $(0.057)$ & & & $0.064 * *$ & $(0.027)$ & & & 0.002 & $(0.001)$ \\
\hline self-employed & $0.087 * *$ & $(0.035)$ & 0.030 & $(0.069)$ & & & $0.077 * *$ & $(0.033)$ & & & -0.000 & $(0.001)$ \\
\hline income & $0.098 * * *$ & (0.024) & $0.160 * * *$ & $(0.020)$ & & & $0.098 * * *$ & $(0.014)$ & & & 0.000 & $(0.001)$ \\
\hline wealth (non-RA) & $0.008 * * *$ & $(0.001)$ & $0.004 * * *$ & $(0.002)$ & & & $0.007 * *$ & $(0.003)$ & & & $0.001 * *$ & $(0.001)$ \\
\hline Observations & 9,240 & & 2,438 & & & & 2,492 & & & & 1,749 & \\
\hline
\end{tabular}

Standard errors in parenthese; ${ }^{* * *} \mathrm{p}<0.01, * * \mathrm{p}<0.05, * \mathrm{p}<0.1 \mathrm{~s}$

Note: S- singles; $\mathrm{SP}$ - single parents; $\mathrm{CP}$-couples without kids; CPK - couples with kids. 
Table A.5: Descriptive statistics (means) by country and age groups.

\begin{tabular}{|c|c|c|c|c|c|c|c|}
\hline 25 to 49 year olds & US & Canada & Germany & Italy & Luxembourg & Spain & Total \\
\hline age & 38.04 & 37.37 & 38.70 & 39.63 & 38.75 & 38.74 & 38.48 \\
\hline male $(0 / 1)$ & 0.78 & 0.61 & 0.52 & 0.66 & 0.45 & 0.50 & 0.62 \\
\hline no. of children lt 18 & 1.34 & 0.42 & 0.79 & 0.94 & 1.00 & 0.93 & 0.98 \\
\hline $\mathrm{s} * 100$ & 20.59 & 33.42 & 36.51 & 27.50 & 24.08 & 19.21 & 29.41 \\
\hline $\mathrm{sp} * 100$ & 15.18 & 7.92 & 11.02 & 6.47 & 6.52 & 9.59 & 11.96 \\
\hline $\mathrm{cp} * 100$ & 15.74 & 22.11 & 16.53 & 16.26 & 15.06 & 11.32 & 16.15 \\
\hline $\mathrm{cpk} * 100$ & 48.49 & 36.55 & 35.94 & 49.78 & 54.34 & 59.88 & 42.28 \\
\hline married & 0.53 & 0.56 & 0.42 & 0.66 & 0.58 & 0.71 & 0.49 \\
\hline divorced & 0.22 & 0.08 & 0.20 & 0.12 & 0.13 & 0.10 & 0.19 \\
\hline low education & 0.14 & 0.13 & 0.11 & 0.50 & 0.30 & 0.38 & 0.16 \\
\hline high education & 0.32 & 0.31 & 0.22 & 0.13 & 0.34 & 0.22 & 0.26 \\
\hline employed & 0.78 & 0.81 & 0.71 & 0.67 & 0.80 & 0.63 & 0.73 \\
\hline self-employed & 0.11 & 0.07 & 0.07 & 0.21 & 0.05 & 0.11 & 0.09 \\
\hline retired & 0.00 & 0.00 & 0.00 & 0.01 & 0.00 & 0.01 & 0.00 \\
\hline income & 11.32 & 10.47 & 10.25 & 10.59 & 11.52 & 10.53 & 10.66 \\
\hline wealth (non-PR) & 3.61 & -0.25 & 2.66 & 6.81 & 7.86 & 6.86 & 3.35 \\
\hline 50 and over & US & Canada & Germany & Italy & Luxembourg & Spain & Total \\
\hline age & 64.89 & 63.94 & 67.28 & 67.12 & 64.69 & 65.54 & 66.41 \\
\hline male $(0 / 1)$ & 0.67 & 0.60 & 0.58 & 0.62 & 0.51 & 0.52 & 0.61 \\
\hline no. of children lt 18 & 0.36 & 0.04 & 0.08 & 0.12 & 0.19 & 0.05 & 0.16 \\
\hline $\mathrm{s} * 100$ & 35.60 & 40.41 & 48.17 & 40.56 & 35.82 & 29.67 & 42.84 \\
\hline $\mathrm{sp} * 100$ & 8.84 & 0.67 & 0.90 & 1.10 & 4.58 & 12.37 & 3.70 \\
\hline $\mathrm{cp} * 100$ & 39.12 & 54.91 & 45.78 & 50.32 & 36.62 & 28.61 & 43.54 \\
\hline $\mathrm{cpk} * 100$ & 16.44 & 3.64 & 4.02 & 8.01 & 22.98 & 29.35 & 9.67 \\
\hline married & 0.52 & 0.53 & 0.48 & 0.58 & 0.58 & 0.58 & 0.51 \\
\hline divorced & 0.41 & 0.01 & 0.43 & 0.33 & 0.34 & 0.34 & 0.40 \\
\hline low education & 0.17 & 0.32 & 0.19 & 0.74 & 0.46 & 0.70 & 0.25 \\
\hline high education & 0.30 & 0.20 & 0.20 & 0.08 & 0.22 & 0.14 & 0.22 \\
\hline employed & 0.40 & 0.37 & 0.24 & 0.16 & 0.24 & 0.19 & 0.28 \\
\hline self-employed & 0.11 & 0.06 & 0.05 & 0.10 & 0.03 & 0.07 & 0.07 \\
\hline retired & 0.47 & 0.48 & 0.50 & 0.68 & 0.43 & 0.39 & 0.50 \\
\hline income & 11.21 & 10.37 & 10.58 & 10.71 & 11.44 & 10.40 & 10.76 \\
\hline wealth (non-PR) & 8.53 & 4.97 & 5.88 & 8.13 & 9.46 & 8.99 & 6.93 \\
\hline
\end{tabular}

Note: S- singles; SP - single parents; CP -couples without kids; CPK - couples with kids. 
Table A.6: Decomposition of portfolio participation decision for households with head 50 and over (Home, Investment Real Estate, and Debt).

\begin{tabular}{|c|c|c|c|c|c|c|c|c|c|c|}
\hline & $\begin{array}{c}\text { Canada } \\
\text { (1) }\end{array}$ & $\%$ & $\begin{array}{c}\text { Germany } \\
(2)\end{array}$ & $\%$ & $\begin{array}{c}\text { Italy } \\
(3)\end{array}$ & $\%$ & $\begin{array}{c}\text { Luxembourg } \\
\text { (4) }\end{array}$ & $\%$ & $\begin{array}{l}\text { Spain } \\
(5)\end{array}$ & $\%$ \\
\hline \multicolumn{11}{|c|}{ Principal Residence } \\
\hline $\operatorname{sex}$ & $0.002 * * *$ & 3 & $-0.001 * * *$ & -1 & $-0.001 * * *$ & -2 & $-0.003 * * *$ & -44 & $-0.003 * * *$ & -7 \\
\hline $\operatorname{demog} 1$ & $0.006 * *$ & 9 & $0.005 * * *$ & 7 & $-0.007 * * *$ & -12 & $-0.001 *$ & -15 & $-0.004 * * *$ & -9 \\
\hline $\operatorname{demog} 2$ & $0.008 * * *$ & 12 & $0.014 * * *$ & 21 & $0.007 * * *$ & 12 & $0.010 * * *$ & 148 & $0.003 * * *$ & 7 \\
\hline $\operatorname{demog} 3$ & -0.002 & -3 & $0.012 * * *$ & 18 & $0.016 * * *$ & 28 & $0.003 * * *$ & 44 & $0.003 * * *$ & 7 \\
\hline educ & $0.008 * * *$ & 12 & -0.000 & 0 & $0.040 * * *$ & 69 & $0.019 * * *$ & 281 & $0.035 * * *$ & 79 \\
\hline LM & $0.005^{*}$ & 7 & $0.011 *$ & 16 & $0.005^{*}$ & 9 & 0.015 & 222 & 0.017 & 39 \\
\hline asini & $0.012 * * *$ & 17 & $0.009 * * *$ & 13 & $0.006 * * *$ & 10 & $-0.007 * * *$ & -104 & $0.011 * * *$ & 25 \\
\hline \multirow[t]{2}{*}{ asinwp } & $0.030 * * *$ & 43 & $0.018 * * *$ & 27 & $-0.008 * * *$ & -14 & $-0.028 * * *$ & -415 & $-0.018 * * *$ & -41 \\
\hline & & 100 & & 102 & & 100 & & 119 & & 100 \\
\hline$P(x=0)$ & 0.809 & & 0.809 & & 0.809 & & 0.809 & & 0.809 & \\
\hline $\mathrm{P}(\mathrm{x}=1)$ & 0.727 & & 0.478 & & 0.784 & & 0.784 & & 0.885 & \\
\hline Diff & 0.0822 & & 0.331 & & 0.0255 & & 0.025 & & -0.076 & \\
\hline Exp & 0.0692 & 9 & 0.0669 & 8 & 0.0578 & 7 & 0.007 & 1 & 0.044 & 5 \\
\hline Unexp & 0.013 & 2 & 0.264 & 33 & -0.032 & -4 & 0.019 & 2 & -0.120 & -15 \\
\hline \multicolumn{11}{|c|}{ Investment Real Estate } \\
\hline $\operatorname{sex}$ & 0.002 & 2 & 0.002 & 3 & 0.001 & 1 & 0.004 & 19 & 0.003 & 3 \\
\hline $\operatorname{demog} 1$ & 0.001 & 1 & 0.005 & 7 & 0.003 & 4 & -0.002 & -10 & -0.001 & -1 \\
\hline $\operatorname{demog} 2$ & $-0.003 * * *$ & -3 & $-0.007 * * *$ & -10 & $-0.006 * * *$ & -7 & 0.000 & 0 & $0.003 *$ & 3 \\
\hline demog 3 & 0.000 & 0 & -0.001 & -1 & -0.001 & -1 & -0.001 & -5 & -0.000 & 0 \\
\hline educ & $0.017 * * *$ & 20 & $0.007 * * *$ & 10 & $0.063 * * *$ & 74 & $0.026 * * *$ & 124 & $0.053 * * *$ & 54 \\
\hline LM & $0.004 * *$ & 5 & 0.002 & 3 & $-0.005 * *$ & -6 & 0.004 & 19 & 0.002 & 2 \\
\hline asini & $0.044 * * *$ & 51 & $0.028 * * *$ & 41 & $0.027 * * *$ & 32 & $-0.003 * *$ & -14 & $0.036 * * *$ & 37 \\
\hline asinwi & $0.022 * * *$ & 25 & $0.032 * * *$ & 46 & $0.004 * * *$ & 5 & $-0.008 * * *$ & -38 & 0.001 & 1 \\
\hline & & 100 & & 99 & & 101 & & 96 & & 99 \\
\hline$P(x=0)$ & 0.244 & & 0.244 & & 0.244 & & 0.244 & & 0.244 & \\
\hline $\mathrm{P}(\mathrm{x}=1)$ & 0.197 & & 0.153 & & 0.259 & & 0.350 & & 0.429 & \\
\hline Diff & 0.0477 & & 0.0912 & & -0.0151 & & -0.105 & & -0.185 & \\
\hline Exp & 0.0868 & 36 & 0.0690 & 28 & 0.0849 & 35 & 0.0209 & 9 & 0.0979 & 40 \\
\hline Unexp & -0.039 & -16 & 0.022 & 9 & -0.100 & -41 & -0.126 & -52 & -0.283 & -116 \\
\hline \multicolumn{11}{|l|}{ Mortgage } \\
\hline sex & -0.001 & -2 & -0.001 & -1 & -0.001 & 0 & -0.003 & -8 & -0.003 & -4 \\
\hline demog 1 & $0.023 * * *$ & 41 & $0.040 * * *$ & 47 & $0.030 * * *$ & 22 & -0.002 & 0 & 0.003 & 4 \\
\hline $\operatorname{demog} 2$ & $0.003 * *$ & 5 & 0.003 & 4 & -0.003 & 0 & 0.000 & 0 & $-0.012 * * *$ & -15 \\
\hline $\operatorname{demog} 3$ & $-0.004 * * *$ & -7 & $0.013 * * *$ & 15 & $0.012 * * *$ & 9 & 0.002 & 6 & $-0.002 * * *$ & -3 \\
\hline educ & $0.017 * * *$ & 31 & $0.005 * * *$ & 6 & $0.059 * * *$ & 43 & $0.028 * * *$ & 78 & $0.056 * * *$ & 83 \\
\hline LM & 0.004 & 7 & $0.013 * *$ & 15 & $0.030 * * *$ & 22 & 0.012 & 34 & 0.011 & 16 \\
\hline asini & $0.016 * * *$ & 29 & $0.013 * * *$ & 15 & $0.009 * * *$ & 7 & $-0.002 * * *$ & -6 & $0.014 * * *$ & 21 \\
\hline & & 104 & & 100 & & 102 & & 103 & & 102 \\
\hline $\mathrm{P}(\mathrm{x}=0)$ & 0.413 & & 0.413 & & 0.413 & & 0.413 & & 0.413 & \\
\hline $\mathrm{P}(\mathrm{x}=1)$ & 0.230 & & 0.137 & & 0.0622 & & 0.149 & & 0.0878 & \\
\hline Diff & 0.183 & & 0.275 & & 0.351 & & 0.263 & & 0.325 & \\
\hline Exp & 0.0557 & 13 & 0.0856 & 21 & 0.137 & 33 & 0.0358 & 9 & 0.0677 & 16 \\
\hline Unexp & 0.127 & 31 & 0.189 & 46 & 0.214 & 52 & 0.227 & 55 & 0.257 & 62 \\
\hline \multicolumn{11}{|c|}{ Non-housing debt } \\
\hline sex & $-0.004 * * *$ & 280 & $-0.007 * * *$ & -34 & $-0.005 * * *$ & -5 & & & $-0.013 * * *$ & -254 \\
\hline demog 1 & $0.013 * * *$ & -909 & $0.024 * * *$ & 117 & $0.019 * * *$ & 19 & & & 0.004 & 78 \\
\hline $\operatorname{demog} 2$ & -0.001 & 70 & -0.000 & 0 & $-0.004 *$ & -4 & & & -0.002 & -39 \\
\hline $\operatorname{demog} 3$ & $-0.004 * * *$ & 280 & $0.028 * * *$ & 137 & $0.026 * * *$ & 26 & & & 0.000 & 0 \\
\hline educ & $0.006^{* *}$ & -420 & $-0.011 * * *$ & -54 & $0.047 * * *$ & 47 & & & $0.049 * * *$ & 957 \\
\hline LM & $-0.008 * *$ & 559 & -0.011 & -54 & $0.020 * * *$ & 20 & & & $-0.029 * *$ & -566 \\
\hline \multirow[t]{2}{*}{ asini } & -0.003 & 210 & -0.002 & -10 & -0.002 & -2 & & & -0.003 & -59 \\
\hline & & 70 & & 102 & & 100 & & & & 117 \\
\hline$P(x=0)$ & 0.558 & & 0.558 & & 0.558 & & & & 0.558 & \\
\hline $\mathrm{P}(\mathrm{x}=1)$ & 0.433 & & 0.137 & & 0.111 & & & & 0.169 & \\
\hline Diff & 0.125 & & 0.421 & & 0.448 & & & & 0.389 & \\
\hline Exp & -0.001 & 0 & 0.0205 & 4 & 0.101 & 18 & & & 0.005 & 1 \\
\hline Unexp & 0.126 & 23 & 0.401 & 72 & 0.347 & 62 & & & 0.384 & 69 \\
\hline
\end{tabular}

Source: 2005 SFS, 2007 SCF, 2007 SOEP, 2008 SHIW, 2007 PSELL3 and 2008 EFF Note: Details of variable groupings (demog1, educ, etc) found in Table A.2 
Table A.7: Decomposition of portfolio participation decision for households with head over 50 (Financial Assets and Risky Assets).

\begin{tabular}{|c|c|c|c|c|c|c|c|c|c|c|}
\hline & $\begin{array}{l}\text { Canada } \\
\text { (1) }\end{array}$ & $\%$ & $\begin{array}{l}\text { Germany } \\
\text { (2) }\end{array}$ & $\%$ & $\begin{array}{c}\text { Italy } \\
(3)\end{array}$ & $\%$ & $\begin{array}{c}\text { Luxembourg } \\
\text { (4) }\end{array}$ & $\%$ & $\begin{array}{l}\text { Spain } \\
\text { (5) }\end{array}$ & $\%$ \\
\hline \multicolumn{11}{|c|}{ Financial Assets } \\
\hline sex & $0.004 * * *$ & 21 & $0.001 *$ & 11 & $0.003 * * *$ & 12 & $0.003 * * *$ & -41 & $0.004 * * *$ & 30 \\
\hline demog 1 & $0.003^{*}$ & 16 & $0.004 *$ & 45 & 0.000 & 0 & 0.000 & 0 & 0.000 & 0 \\
\hline $\operatorname{demog} 2$ & $-0.002 * *$ & -11 & -0.001 & -11 & -0.001 & -4 & $-0.001 * *$ & 14 & $0.005^{* * *}$ & 38 \\
\hline $\operatorname{demog} 3$ & 0.002 & 11 & $0.002 *$ & 22 & 0.001 & 4 & 0.001 & -14 & 0.002 & 15 \\
\hline educ & $0.016 * * *$ & 86 & $0.003 * *$ & 33 & $0.040 * * *$ & 161 & $0.026 * * *$ & -351 & $0.041 * * *$ & 308 \\
\hline LM & -0.002 & -11 & -0.003 & -33 & $0.003 *$ & 12 & -0.003 & 41 & -0.006 & -45 \\
\hline asini & $0.007 * * *$ & 37 & $0.008 * * *$ & 89 & $0.004 * * *$ & 16 & $-0.006^{* * *}$ & 81 & $0.009 * * *$ & 68 \\
\hline \multirow[t]{2}{*}{ asinwf } & $-0.010 * * *$ & -53 & $-0.005^{* * *}$ & -56 & $-0.026 * * *$ & -104 & $-0.027 * * *$ & 365 & $-0.042 * * *$ & -316 \\
\hline & & 96 & & 100 & & 96 & & 95 & & 98 \\
\hline $\mathrm{P}(\mathrm{x}=0)$ & 0.966 & & 0.966 & & 0.966 & & 0.966 & & 0.966 & \\
\hline $\mathrm{P}(\mathrm{x}=1)$ & 0.914 & & 0.615 & & 0.754 & & 0.719 & & 0.938 & \\
\hline Diff & 0.0519 & & 0.350 & & 0.212 & & 0.247 & & 0.0280 & \\
\hline Exp & 0.0187 & 2 & 0.00898 & 1 & 0.0249 & 3 & -0.00740 & -1 & 0.0133 & 1 \\
\hline Unexp & 0.033 & 3 & 0.341 & 35 & 0.187 & 19 & 0.254 & 26 & 0.015 & 2 \\
\hline \multicolumn{11}{|c|}{ Risky Assets } \\
\hline sex & 0.000 & 0 & na & & 0.000 & 0 & na & & 0.001 & 1 \\
\hline demog1 & $0.006 * * *$ & 4 & & & $0.008 * *$ & 5 & & & -0.001 & -1 \\
\hline $\operatorname{demog} 2$ & $0.005 * * *$ & 3 & & & 0.001 & 1 & & & $-0.004^{*}$ & -5 \\
\hline $\operatorname{demog} 3$ & 0.002 & 1 & & & $-0.008 * * *$ & -5 & & & 0.001 & 1 \\
\hline educ & $0.031 * * *$ & 20 & & & $0.113 * * *$ & 77 & & & $0.099 * * *$ & 125 \\
\hline LM & $-0.013 * * *$ & -8 & & & $-0.013 * * *$ & -7 & & & $-0.069 * * *$ & -87 \\
\hline asini & $0.064 * * *$ & 42 & & & $0.036 * * *$ & 24 & & & $0.058 * * *$ & 74 \\
\hline \multirow[t]{2}{*}{ asinwr } & $0.059 * * *$ & 39 & & & $0.010 * * *$ & 7 & & & $-0.006 * * *$ & -8 \\
\hline & & 101 & & & & 102 & & & & 100 \\
\hline$P(x=0)$ & 0.359 & & & & 0.359 & & & & 0.359 & \\
\hline $\mathrm{P}(\mathrm{x}=1)$ & 0.286 & & & & 0.241 & & & & 0.0417 & \\
\hline Diff & 0.0721 & & & & 0.117 & & & & 0.317 & \\
\hline Exp & 0.153 & 43 & & & 0.147 & 41 & & & 0.0789 & 22 \\
\hline Unexp & -0.081 & -23 & & & -0.030 & -8 & & & 0.238 & 66 \\
\hline
\end{tabular}

Source: 2005 SFS, 2007 SCF, 2007 SOEP, 2008 SHIW, 2007 PSELL3 and 2008 EFF

Note: Details of variable groupings (demog1, educ, etc) found in Table A.2 
Figure A.1 Linear regressions between the unexplained participation gap in Principal Residence and the institutional setting.

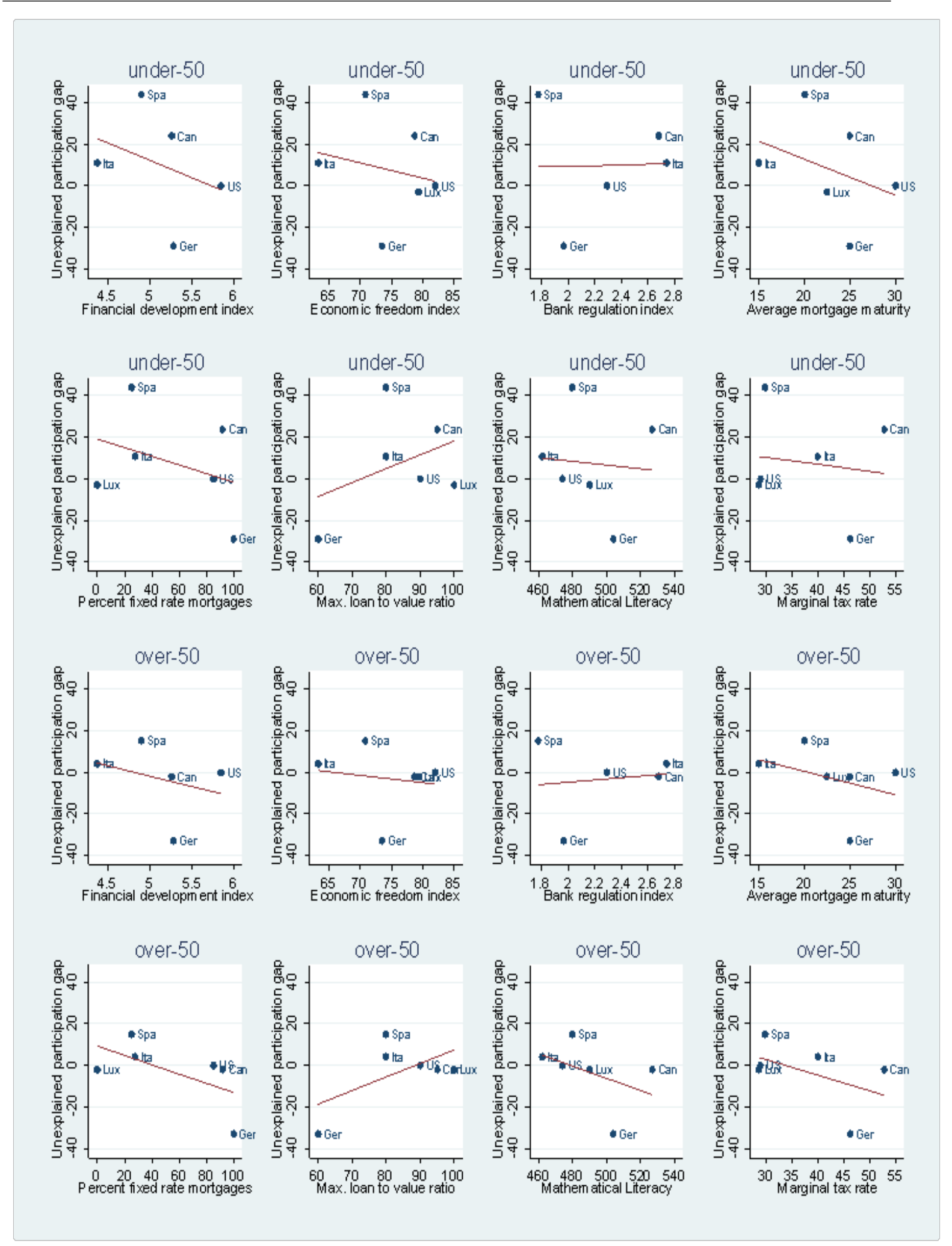

Source: 2005 SFS, 2007 SCF, 2007 SOEP, 2008 SHIW, 2007 PSELL3 and 2008 EFF 
$\overline{\text { Figure A.2 Linear regressions between the unexplained participation gap in Investment }}$ Real Estate and the institutional setting.

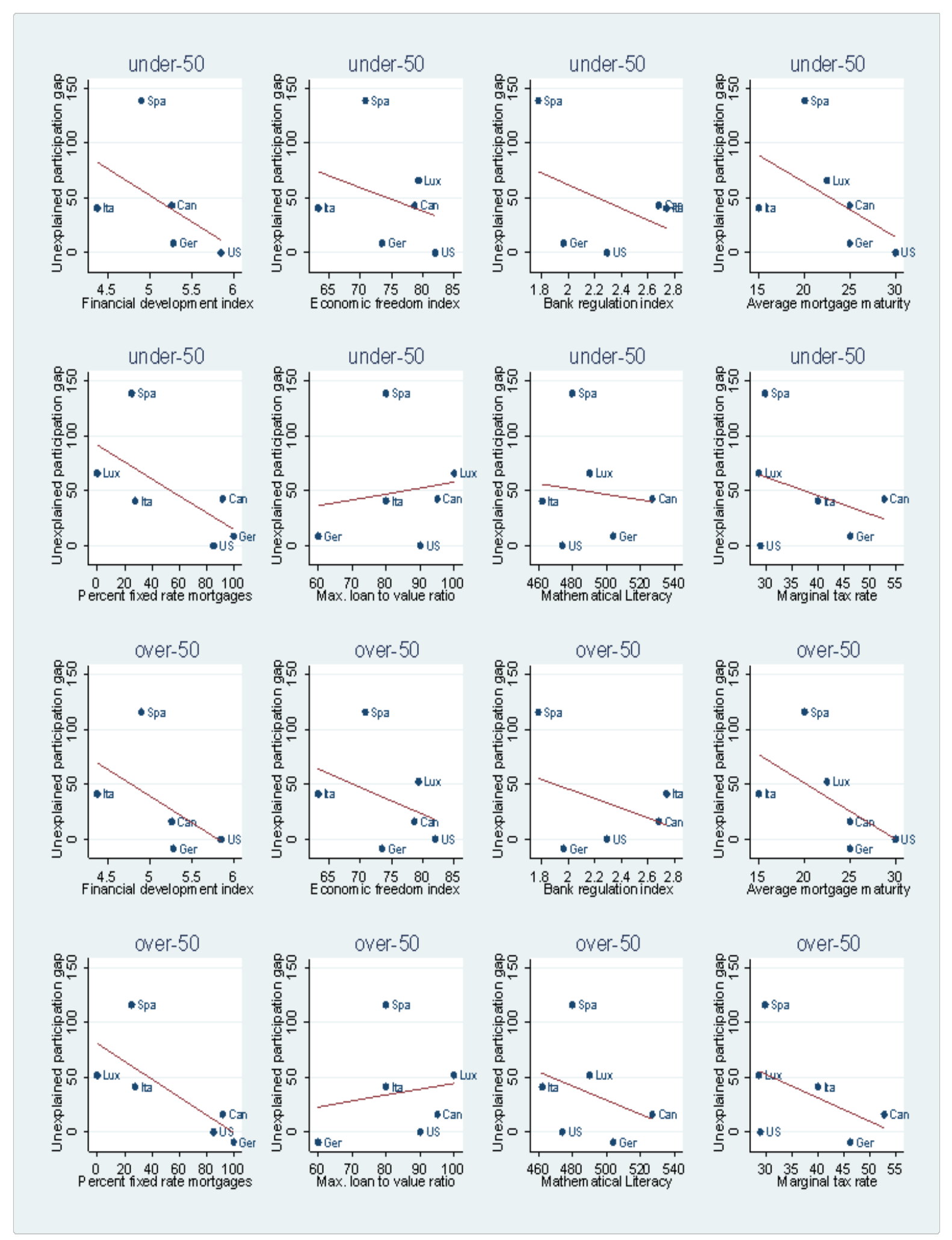

Source: 2005 SFS, 2007 SCF, 2007 SOEP, 2008 SHIW, 2007 PSELL3 and 2008 EFF 
$\overline{\text { Figure A.3 Linear regressions between the unexplained participation gap in Mortgages }}$ and the institutional setting.

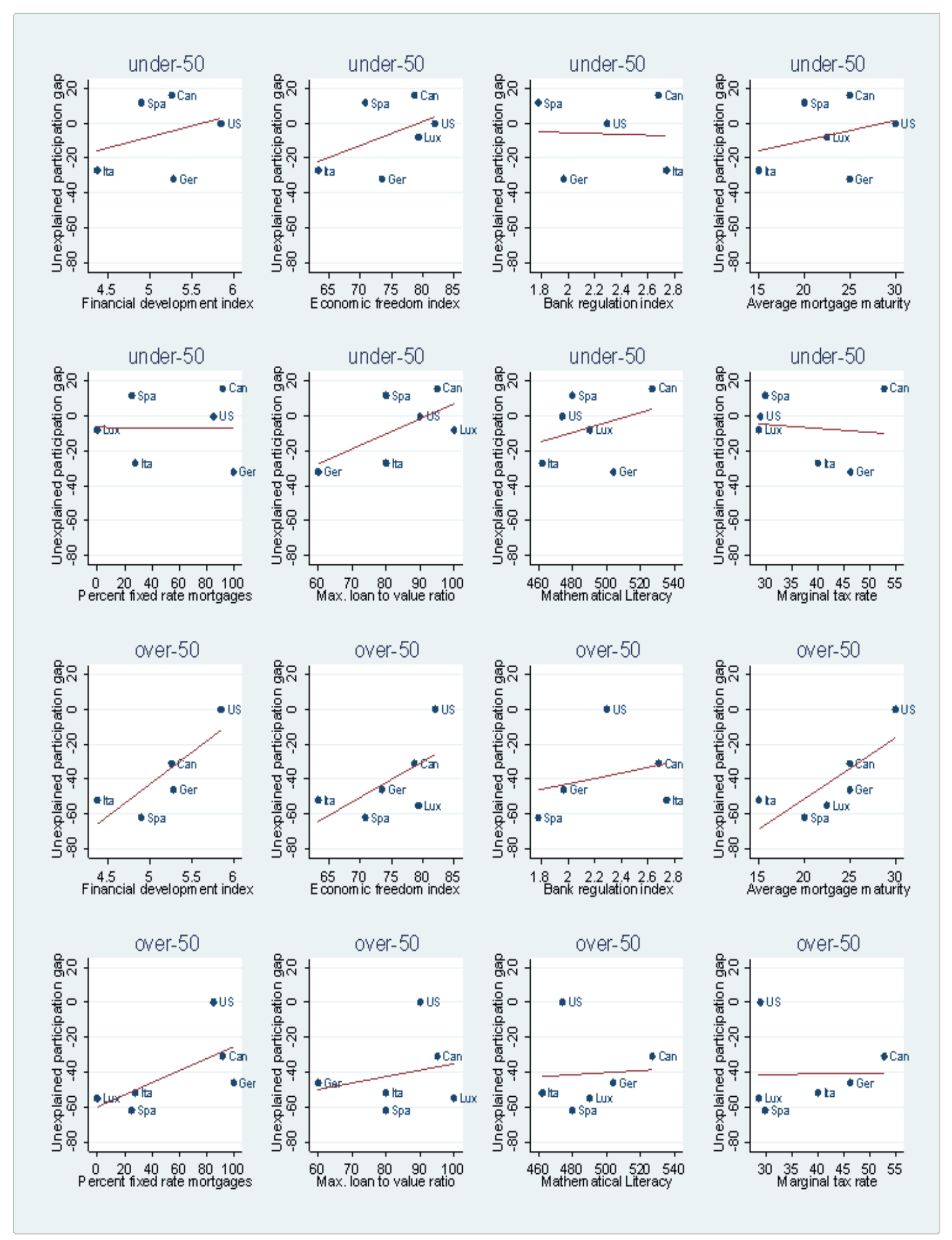

Source: 2005 SFS, 2007 SCF, 2007 SOEP, 2008 SHIW, 2007 PSELL3 and 2008 EFF 
$\overline{\text { Figure A.4 Linear regressions between the unexplained participation gap in Non-Housing }}$ Debt and the institutional setting.

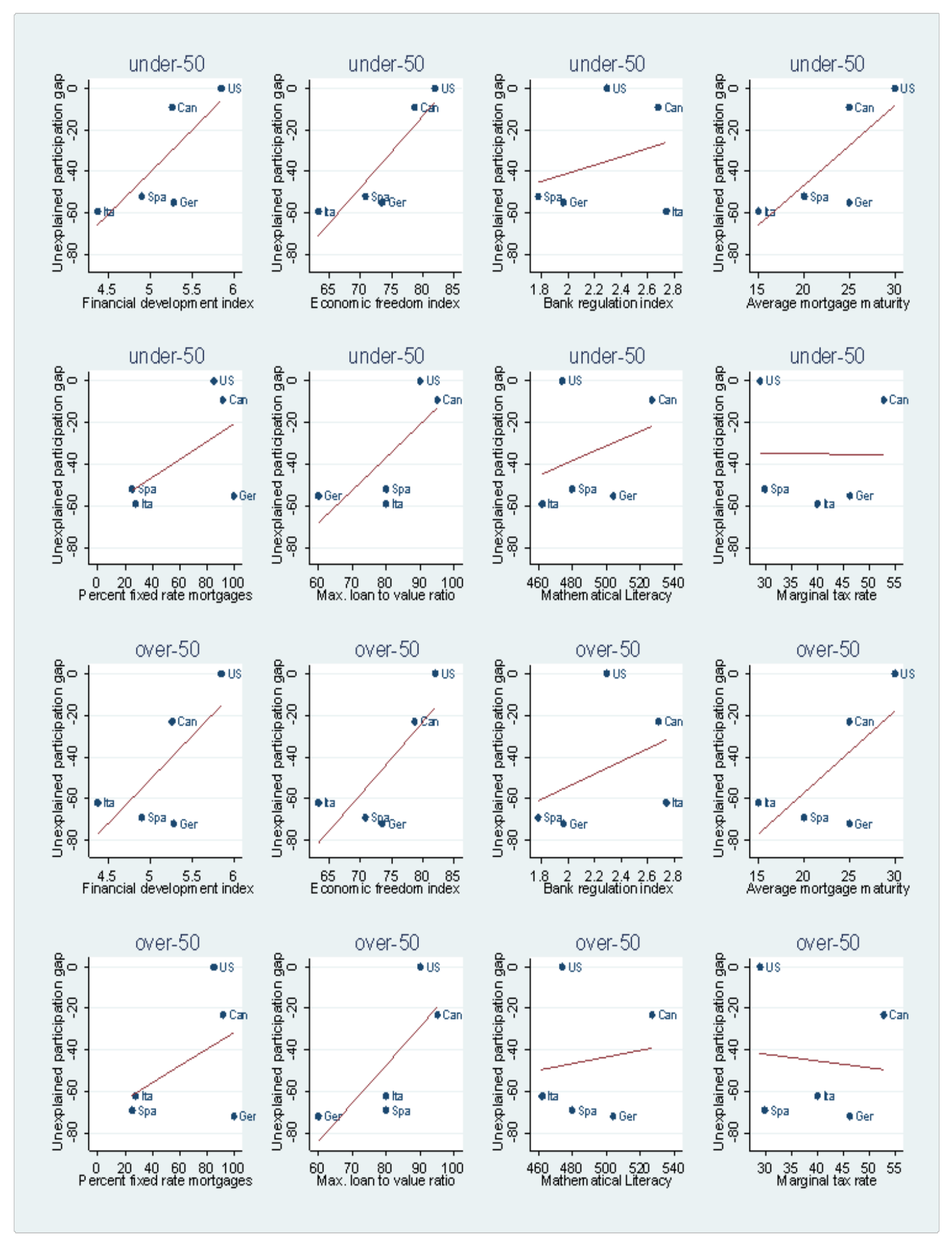

Source: 2005 SFS, 2007 SCF, 2007 SOEP, 2008 SHIW, 2007 PSELL3 and 2008 EFF 